\title{
International Reserves in Emerging Market Countries: Too Much of a Good Thing?
}

WiTH INTERNATIONAL reserves four times as large, in terms of their GDP, as in the early 1990s, emerging market countries seem more protected than ever against shocks to their current and capital accounts. Some have argued that this buildup in reserves might be warranted as insurance against the increased volatility of capital flows associated with financial globalization. ${ }^{1}$ Others view this development as the unintended consequence of large current account surpluses and suggest that the level of international reserves has become excessive in many of these countries. ${ }^{2}$

I thank Ioannis Tokatlidis for superb research assistance. I also thank my discussants, Joshua Aizenman and Lawrence Summers, as well as Eduardo Borensztein, Stijn Claessens, Fernando Goncalves, Pierre-Olivier Gourinchas, Nancy Marion, Jonathan Ostry, Brad Setser, and Shang-Jin Wei for comments on earlier drafts. This paper benefited from discussions with Romain Rancière (who also generously shared data) and Christian Mulder. The views expressed in this paper are those of the author and should not be attributed to the International Monetary Fund, its Executive Board, or its management.

1. See, for example, Aizenman and Marion (2003) and Stiglitz (2006). According to a survey of central bankers of developing and emerging market countries, the main reason for the recent buildup in reserves was to "secure protection from volatile capital flows" (Pringle and Carver, 2005). In the words of Stiglitz (2006, p. 248) "The East Asian countries that constitute the class of ' 97 - the countries that learned the lessons of instability the hard way in the crises that began in that year: have boosted their reserves in part because they want to make sure that they won't need to borrow from the IMF again. Others, who saw their neighbors suffer, came to the same conclusion-it is imperative to have enough reserves to withstand the worst of the world's economic vicissitudes."

2. See, for example, Summers (2006). 
Do emerging market countries hold too much international reserves, and are there better ways to use those funds?

Answering these questions requires a normative benchmark for the optimal level of reserves. I present in this paper a simple welfare-based model of the optimal level of reserves to deal with the risk of capital account crises or of "sudden stops" in capital flows. On the basis of this model, I derive some formulas for the optimal level of reserves and compare them with conventional rules of thumb, such as the GreenspanGuidotti rule of full coverage of short-term debt. I then calibrate the model for emerging market countries and compare its predictions with the actual data.

One lesson from this exercise is that the optimal level of reserves is subject to considerable uncertainty, because it is sensitive to certain parameters that are difficult to measure. The model nevertheless produces ranges of plausible estimates against which the data can be compared. I find that it is not difficult for the model to explain a reserves-GDP ratio on the order of 10 percent for the typical emerging market country (close to the long-run historical average), and that even higher ratios can be justified if one assumes that reserves have a significant role in crisis prevention. The levels of reserves observed in many countries in the recent period, in particular in Latin America, are within the range of the model's predictions.

Ultimately, however, the insurance model fails to account for the recent pattern of reserves accumulation in emerging market countries. The reason is that most of the reserves accumulation has taken place in Asian emerging market countries, where the risk of a capital account crisis seems much too small to justify such levels of self-insurance. The insurance model can account for the reserves accumulation observed in the Asian emerging market countries only if one assumes that the expected cost of a capital account crisis is unrealistically large (more than 60 percent of GDP for one of the two major types of crisis examined).

The conclusion that most of the current buildup of reserves is not justified by precautionary reasons has some implications for reserves management. There is little reason for countries to invest these funds in the liquid but low-yielding foreign assets in which central banks tend to invest. Rather, reserves should be viewed as a component of domestic external wealth that is managed by the public sector on behalf of the domestic citizenry, taking full advantage of the portfolio diversification opportunities available abroad. Indeed, an increasing number of emerging market coun- 
tries are transferring a fraction of their reserves to "sovereign wealth funds," mandated to invest in a more diversified way and at a longer horizon than central banks normally do. This is a trend that might take on considerable importance looking forward.

The last part of the paper discusses some policy challenges and opportunities implied by the buildup in emerging market countries' "sovereign wealth." I discuss, first, the impact of sovereign wealth diversification on global financial markets, and second, some ways in which this wealth could be used in collective international arrangements - to insure against future crises or to promote financial development.

\section{The Buildup in International Reserves}

The growth in the international reserves of emerging market countries is striking when compared with the contemporaneous trends in reserves in industrial countries (figure 1). ${ }^{3}$ Whereas reserves in a group of industrial countries have remained stable below 5 percent of GDP, reserves in the emerging market countries have grown more than fourfold in terms of GDP since 1990. Much of this accumulation-more than half of the dollar amount-has taken place in Asia since the 1997-98 Asian crisis. China now has the largest stock of international reserves in the world, having overtaken Japan at the end of 2005, and it accounts for an important share of the buildup in emerging market reserves. However, China is not very different from the other Asian emerging market countries in terms of its ratio of reserves to GDP.

This development is an important dimension of what Lawrence Summers calls the "capital flows paradox" in the current world financial system, ${ }^{4}$ namely, that capital is flowing upstream from developing and emerging market countries toward the industrialized world and principally the United States. The reserves accumulated in my sample of emerging

3. My sample of emerging market countries is based on JP Morgan's Emerging Markets Bond Index Global (EMBIG); my sample of industrial countries includes all countries that were members of the Organization for Economic Cooperation and Development in 1990. Appendix table A-1 lists the countries in both samples. Neither sample includes three large reserves holders in Asia: Hong Kong, Singapore, and Taiwan.

4. Summers (2006). 
Figure 1. International Reserves in Emerging Market and Industrial Countries, 1980-2005

Trillions of current dollars

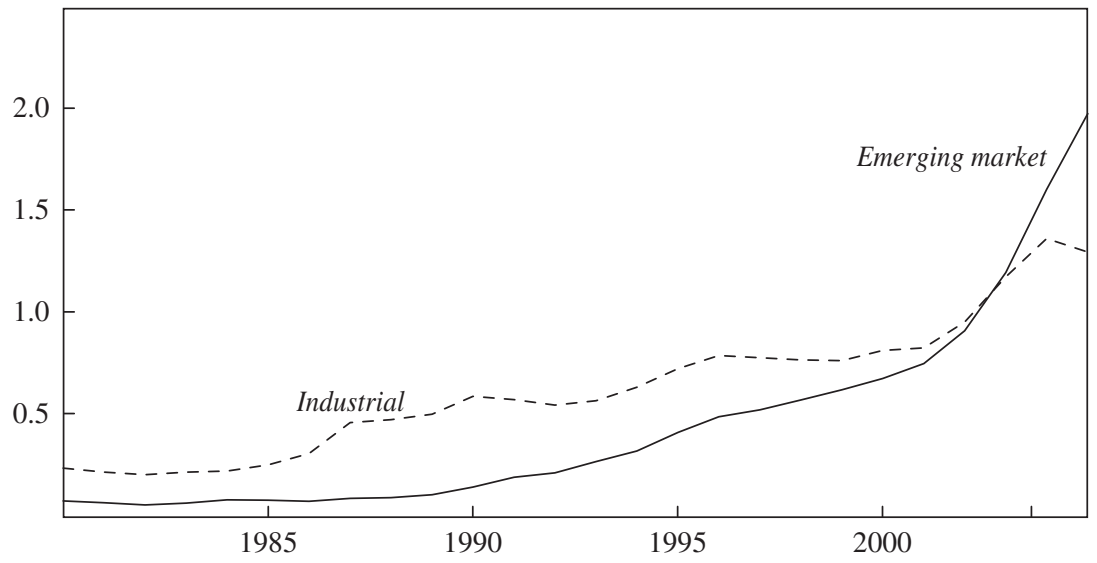

Percent of GDP ${ }^{b}$

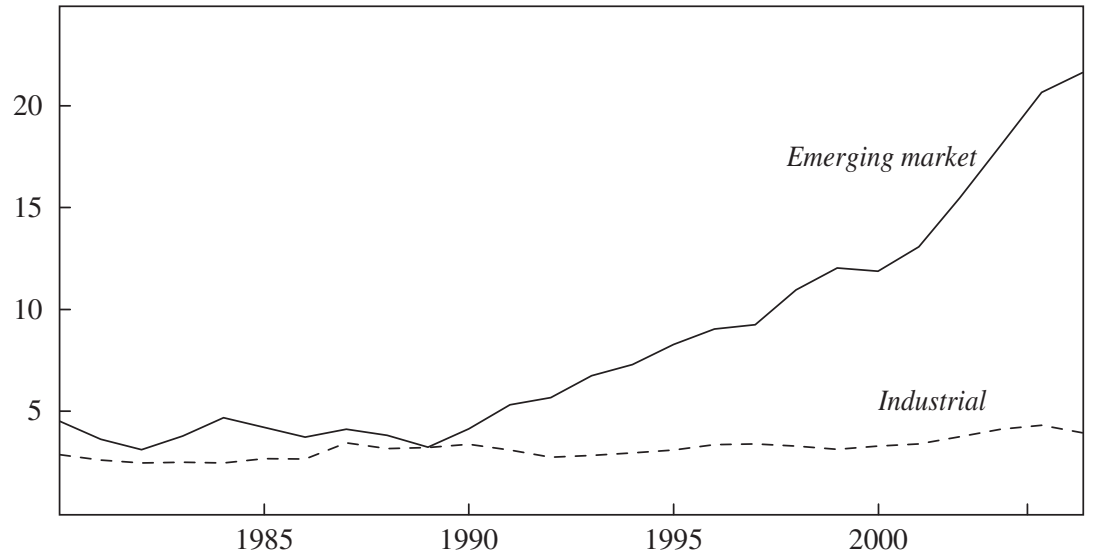

Sources: IMF, International Financial Statistics; World Bank, World Development Indicators.

a. Total reserves minus gold. Countries included in each group are listed in appendix table A-1.

b. Unweighted averages of reserves as a percent of GDP in the countries in each group. 
Table 1. Reserves Accumulation and the Financial Account in Emerging Market Countries, 2000-05

Percent

\begin{tabular}{lccc}
\hline Item & $\begin{array}{c}\text { All emerging } \\
\text { market countries }\end{array}$ & Asia & Latin America \\
\hline $\begin{array}{l}\text { Net capital inflows as share of } \\
\quad \text { change in reserves }\end{array}$ & 40.6 & 36.6 & 137.0 \\
$\begin{array}{l}\text { Composition of the increase in } \\
\quad \text { gross foreign assets }\end{array}$ & & & \\
$\begin{array}{l}\text { Direct investment } \\
\text { Portfolio investment }\end{array}$ & 8.8 & 5.6 & 20.9 \\
Other investment & 8.7 & 8.7 & 13.0 \\
Reserve assets & 22.3 & 11.7 & 36.0 \\
$\quad$ Composition of the increase in & 60.2 & 73.9 & 30.0 \\
$\quad$ gross foreign liabilities & & & \\
Direct investment & & & \\
Portfolio investment & 67.9 & 63.3 & 104.0 \\
Other investment & 20.9 & 28.2 & 6.8 \\
\hline
\end{tabular}

Source: IMF, Balance of Payments Statistics.

a. The data come from the standard presentation of the Balance of Payments Statistics. Net capital inflows are computed as the sum of the financial account over the period 2000-05. Reserve assets include foreign exchange reserves, monetary gold, special drawing rights, and the reserve position in the International Monetary Fund.

market countries between 2000 and 2005 are equal to a significant fraction (about 40 percent) of the U.S. current account deficit in the same period and may thus have contributed to keeping global interest rates low.

Table 1 provides some insights on whether the reserves buildup has tended to be financed by current account surpluses or through capital inflows. The first line of the table reports cumulative net capital inflows as a percent of the increase in reserves over 2000-05 for the sample of emerging market countries, with a breakdown for Asia and Latin America. About 40 percent of the reserves buildup has been financed by capital inflows on average. Whereas Asia has relied more than the average on net exports to accumulate reserves, Latin America has run current account deficits, so that its (relatively smaller) increase in reserves has had to be financed more than one for one by capital inflows.

Another way to look at reserves is in the broader context of the country's external balance sheet. The bottom two panels of table 1 show the composition of the increase in both external assets and external liabilities that were traded in the financial accounts of emerging market countries between 2000 and 2005. More than 60 percent of their foreign asset accumulation consisted of reserves (more than 70 percent in Asia). By contrast, 
Figure 2. Composition of the Stock of Foreign Assets and Liabilities in Emerging Market and Industrial Countries, 2000-05 Averages

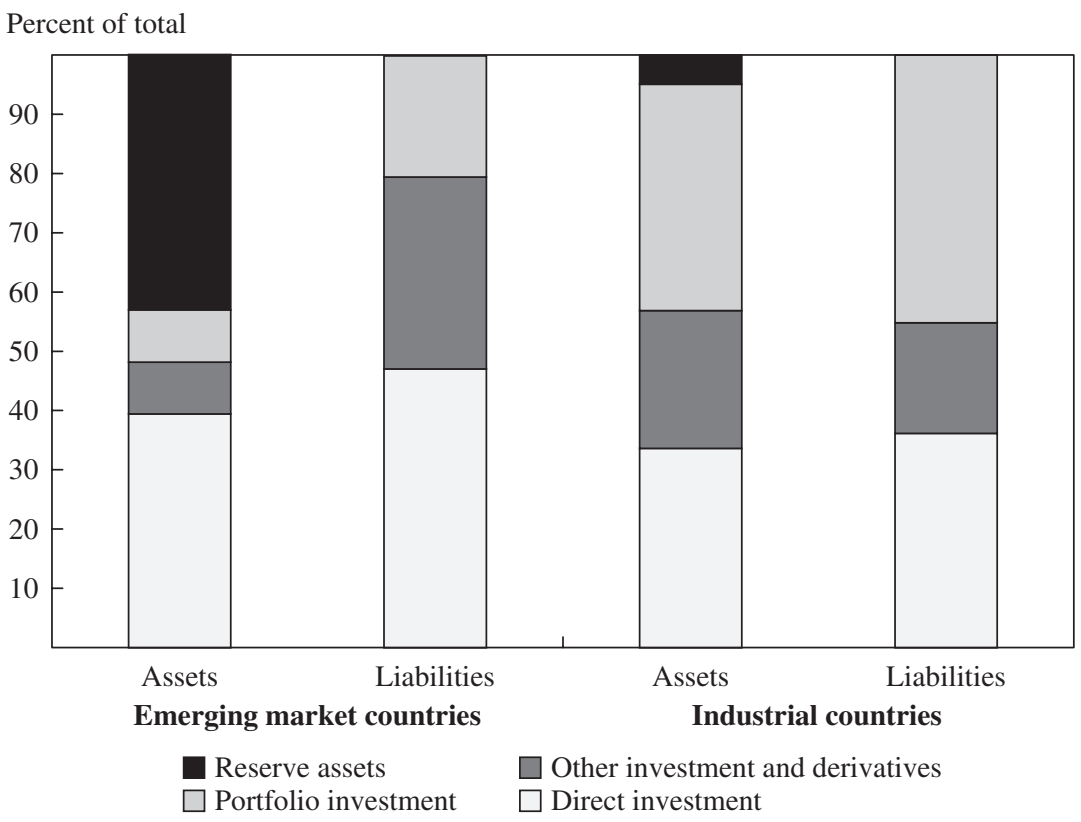

Sources: IMF, Balance of Payments Statistics.

foreign direct investment (FDI) accounted for almost 70 percent of the new liabilities accumulated by these countries.

That emerging market countries tend to have external assets that are more liquid than their external liabilities is confirmed by looking at stocks rather than flows. Figure 2 compares the external balance sheets of emerging market and industrial countries (taking the average over 2000-05), using the International Monetary Fund (IMF) data on international investment positions. The share of reserves in gross foreign assets is almost nine times as large in the emerging market countries as in the industrial countries, whereas the share of FDI in their liabilities is almost twice as large.

The level of reserves in emerging market countries has thus increased since the early 1990s, but so has their trade and financial integration-and with it the associated risks. How much of the increase in reserves can be explained as self-insurance in response to an increase in the hazards of globalization? 
As numerous studies have pointed out, the recent accumulation of reserves by emerging market countries seems difficult to explain using the conventional rules of thumb for reserves adequacy. Figure 3 tracks three conventional reserves adequacy ratios in emerging market countries since 1980: the ratios of reserves to imports, to short-term external debt, and to broad money (M2). ${ }^{5}$ Although imports and M2 have increased over time in these countries, international reserves have increased by much more. All three reserves adequacy ratios have increased markedly and are now much higher than any of the conventional rules of thumb would prescribe. In 2005 reserves in emerging market countries were close to seven months of imports and five times the level of short-term debt. That reserves deviate even more from the Greenspan-Guidotti rule than from the three-months-ofimports rule is surprising, since the former was developed to better capture the risks stemming from the capital account after the crises of the 1990s.

The reserves buildup is also difficult to explain using regression-based empirical models for precautionary reserves. A large empirical literature explains the cross-country and time variation in reserves by a few key variables: economic size of the country, current and capital account vulnerability, and exchange rate flexibility. Recent studies find that although such regressions do a good job of predicting reserve holdings over a long period, they significantly underpredict the reserves accumulation of emerging market countries after the Asian crisis, especially in Asia. ${ }^{6}$

It could be, however, that such regressions fail to capture the impact that the severe capital account crises of the 1990s had on how these countries perceived the risks associated with their international financial integration. It has been argued that the Asian crisis marked a watershed, in that emerging market countries became painfully aware that even sound macroeconomic policies did not insulate them from contagion and sharp reversals in capital flows. The buildup in reserves could be a rational adaptation to this new, more volatile world.

5. The ratio of reserves to imports should equal 0.25 according to the three-monthsof-imports rule. The ratio of reserves to short-term external debt should equal 1 according to the Greenspan-Guidotti rule, the idea being that reserves should allow a country to live without foreign borrowing for up to one year. A conventional range for the ratio of reserves to broad money is 5 to 20 percent. The rationale for this ratio is that broad money reflects a country's exposure to the withdrawal of assets (Calvo, 1996; De Beaufort-Wijnholds, Onno, and Kapteyn, 2001).

6. See IMF (2003), Aizenman and Marion (2003), and Aizenman, Lee, and Rhee (2004). 
Figure 3. Reserves Adequacy Ratios in Emerging Market Countries, 1980-2005

\section{Reserves to imports}

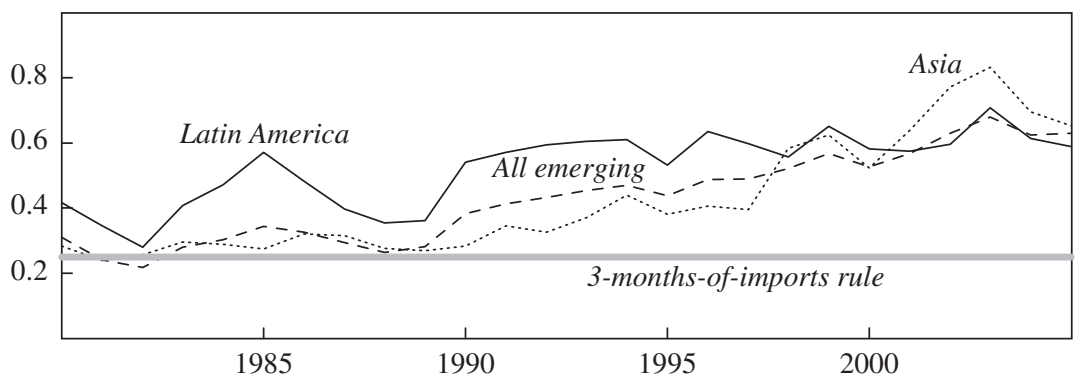

Reserves to short-term debt

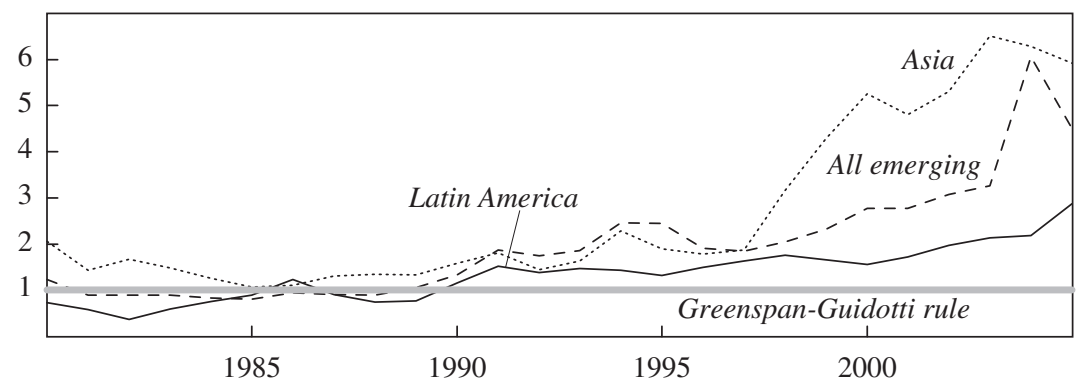

Reserves to $\mathrm{M}^{\mathrm{a}}$

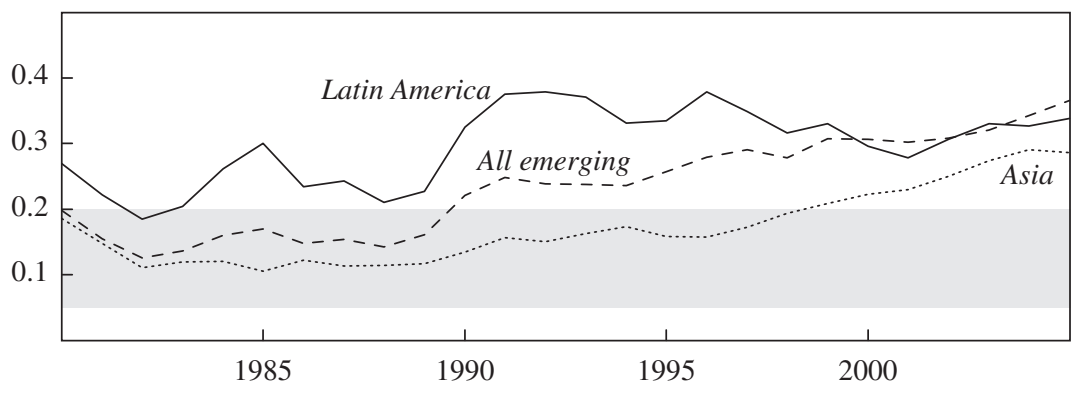

Sources: IMF, International Financial Statistics; World Bank, Global Development Finance. 
Figure 4. Sudden Stops in Emerging Market Countries, 1980-2000a

No. of episodes

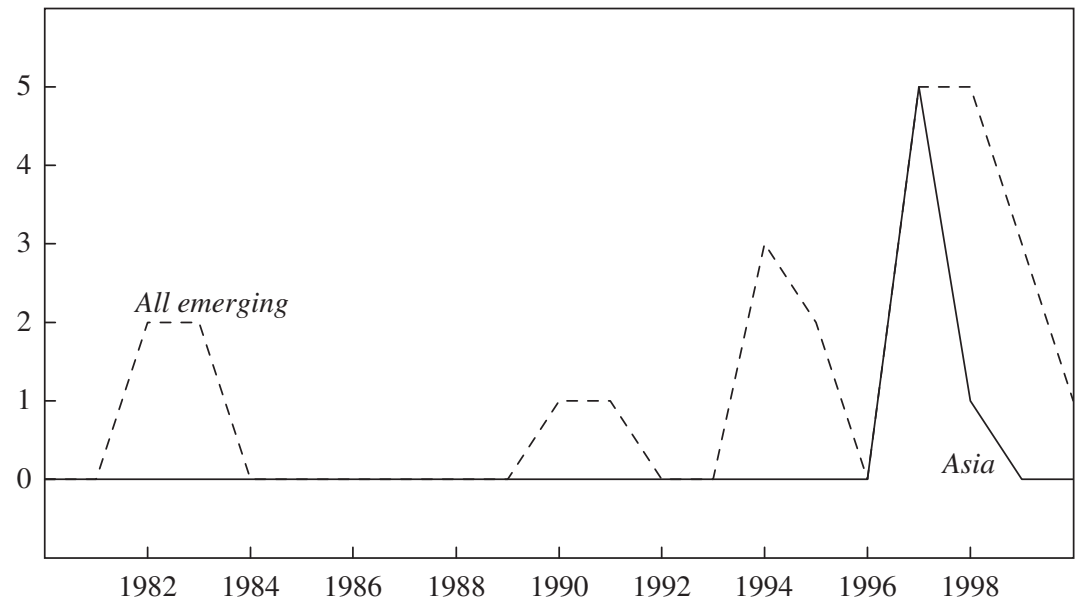

Sources: Frankel and Cavallo (2004); IMF, International Financial Statistics; World Bank, World Development Indicators. a. Using the SS2 definition of a sudden stop. (See table A-2 in appendix A for crisis definitions.)

The concept that came to epitomize the capital account instability of the 1990s is that of a "sudden stop" in capital inflows. Figure 4 shows that although sudden stops were not a total novelty for emerging market countries as a whole, they were a relatively new phenomenon in Asia. For the five Asian countries most affected by the 1997-98 crisis, furthermore, the size of the shock to the capital account and the loss of reserves were unprecedented, in recent decades at least, as figure 5 shows. It may not be a coincidence, from this point of view, that most of the recent buildup in international reserves has taken place in Asia.

In sum, the recent buildup in emerging market countries' international reserves cannot be explained by conventional adequacy ratios or by simple linear regressions. But it may be that neither approach fully captures how the instability of the 1990s changed the perception of risks and the desire for insurance on the part of the countries most affected. For this reason, looking at the implications of a cost-benefit analysis of the optimal level of reserves might be more informative than historical regressions. This is the approach that I take in the rest of the paper. 
Figure 5. Yearly Changes in Reserves Ratio in Five Asian Countries, 1980-2005

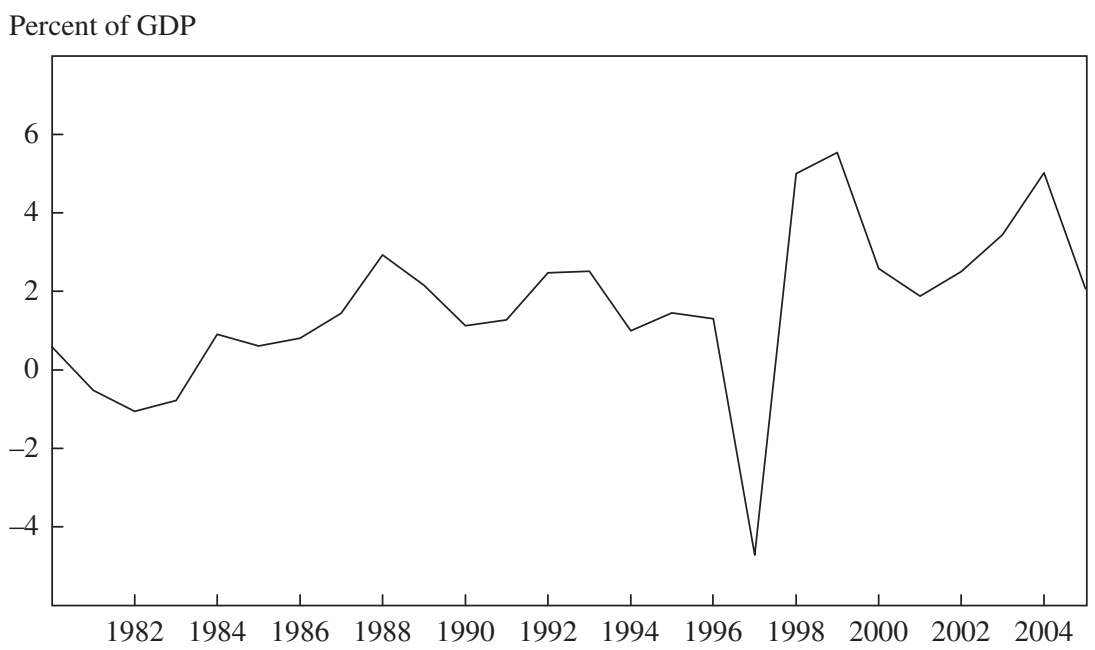

Sources: IMF, International Financial Statistics; World Bank, World Development Indicators.

a. Indonesia, Korea, Malaysia, Philippines, and Thailand. Data include crisis loans received from the IMF.

\section{An Insurance Model of Optimal Reserves}

I present in this section a simple framework for a cost-benefit analysis of the optimal level of reserves to deal with capital account crises. The model features a small, open economy that is subject to being hit by a capital account crisis. Reserves are useful both in terms of crisis prevention (reducing the probability of a crisis) and in terms of crisis mitigation (reducing the welfare cost of a crisis, once it has occurred). I start with a brief review of the literature on cost-benefit analyses of international reserves, before presenting the model.

\section{Cost-Benefit Analyses of the Optimal Level of Reserves}

The idea of a cost-benefit approach to the optimal level of reserves has inspired a long line of literature that goes back to a seminal contribution published by Robert Heller in 1966. ' In Heller's analysis the optimal level

7. Heller (1966). The dynamic aspect of the authorities' optimization problem was treated more rigorously in the buffer stock models of international reserves of Hamada and Ueda (1977) and Frenkel and Jovanovic (1981). 
of reserves was determined in the context of a trade-off between their opportunity cost and the risk of an external disequilibrium leading to a costly adjustment - a contraction in domestic absorption. Heller simply posited that the optimal level of reserves should minimize the sum of the expected cost of adjustment plus the opportunity cost of reserves.

One problem with traditional models of optimal reserves is that the objective function maximized by the authorities is only loosely related to domestic welfare. This leaves room for ambiguity in the definition and in the measurement of key variables of the model. First, it is not very clear how the cost of an external disequilibrium should be measured. ${ }^{8}$ Second, the lack of a rigorous welfare criterion also leads to some ambiguity in the definition of the opportunity cost of reserves, as I will show later.

I will therefore rely on a model of the optimal level of reserves that is welfare-based but preserves some of the simplicity of the earlier literature. This section concludes with a brief summary of the main features of my analytical framework. After reading this summary, those primarily interested in my predictions on the optimal level of reserves can skip the remainder of this section, which presents the model in more detail, and proceed directly to the discussion of the numerical findings.

The model features a small, open economy that is vulnerable to crisis, defined as a loss of access to external credit associated with a fall in output. The economy is populated by a representative consumer who holds a certain amount of foreign assets. ${ }^{9}$ This wealth can be invested in liquid international reserves or an illiquid asset. Reserves yield benefits in terms of crisis prevention and crisis mitigation but entail an opportunity cost relative to the more profitable illiquid investment. The optimal level of reserves will depend on the following parameters of the model:

$L$ and $\Delta Y$, the size of the capital flight and of output loss in a crisis, respectively, expressed in terms of potential output;

8. Whereas Heller (1966) interpreted the adjustment cost as a transitory fall in domestic absorption, Ben Bassat and Gottlieb (1992) and Garcia and Soto (2004) define it as a fall in domestic output. The two are not equivalent for domestic welfare.

9. The representative-consumer assumption implies that one must look at the optimal level of reserves from the point of view of the country as a whole, without distinguishing between the private sector and the public sector. See, for example, Caballero and Krishnamurthy (2004) for a model of international reserves that includes a meaningful distinction between the private sector and the government. 
$\delta$, the opportunity cost of accumulating reserves;

$\sigma$, the relative risk aversion of the domestic consumer; and

$\pi$, the probability of a crisis (which is endogenous to the level of reserves if they have a role in crisis prevention).

\section{Assumptions}

The model assumes a small open economy and three periods of time $t=0,1,2$. The last period (period 2) represents the long term. The intermediate period (period 1) is the time during which a crisis could occur. During the initial period (period 0) the country adjusts its reserves to the risk of a crisis in period 1 . This simple time structure makes it possible to preserve the simplicity of Heller's original approach but does not preclude a more dynamic interpretation of the model, as I will show shortly. ${ }^{10}$

At the end of period 0, a representative consumer in the small open economy structures his or her external assets and liabilities to deal with the risk of a crisis in period 1. To keep the problem simple, I assume that the consumer allocates wealth net of foreign liabilities, $W_{0}$, between two assets: liquid bonds (or reserves, $R_{0}$ ) and an illiquid asset $I$. This asset can be defined as a negative variable, in which case the consumer issues a long-term external liability $D=-I$. The welfare of the representative consumer is given by

$$
U_{t}=E_{t}\left[u\left(C_{1}\right)+\frac{W_{2}}{1+r}\right],
$$

where $u(\cdot)$ is an increasing and concave function of consumption, and $W_{2}$ is the consumer's net foreign wealth at the beginning of period 2. Foreign wealth can be traded between periods at interest rate $r$. The consumer thus desires a level of consumption $C^{*}$ in period 1 that satisfies the first-order condition,

$$
u^{\prime}\left(C^{*}\right)=1
$$

10. Aizenman and Marion (2003) and Miller and Zhang (2006) present two-period precautionary savings models of reserves. Caballero and Panageas (2005) and Durdu, Mendoza, and Terrones (2007) present more dynamic precautionary savings models of international reserves. These models do not yield closed-form solutions for the optimal level of reserves but can be solved numerically. 
The reserves are more liquid than the asset in the sense that they are the only form of wealth that can be sold in period 1 . The illiquid asset cannot be sold in period 1 but brings a higher return in the long run (period 2). The difference between the return on the illiquid asset and the return on reserves is the opportunity cost of reserves, the price that the consumer must pay in order to keep wealth in liquid form.

The sequence of events and actions is as follows:

Period 0 . The consumer allocates wealth net of foreign liabilities between reserves and the illiquid asset,

$$
W_{0}=R_{0}+I
$$

Period 1. An external liability $L$ comes due. The consumer repays $L$ and consumes $C_{1}$ under the budget constraint,

$$
Y_{1}+L^{\prime}+R=C_{1}+L+R^{\prime}
$$

where $Y_{1}$ is domestic output, $L^{\prime}$ is new debt issued in period $1, R=(1+r) R_{0}$ is the stock of reserves at the beginning of the period, and $R^{\prime}$ is the stock of reserves at the end of the period.

Period 2. The consumer's net foreign wealth is equal to output in period 2 plus the net return on net foreign assets,

$$
W_{2}=Y_{2}+(1+r)^{2}(1+\delta) I+(1+r)\left(R^{\prime}-L^{\prime}\right) \text {, }
$$

where $r$ is the interest rate on reserves and external liabilities between periods, and $\delta$ is the excess return on the illiquid asset (or "illiquidity premium").

In period 1 the economy can be in either of two states that differ by the level of output and the consumer's access to external credit:

- the no-crisis state: output is at its potential, $Y_{1}=Y$, and the representative consumer has complete access to external credit (there is no restriction on $L^{\prime}$ ), or

- the crisis state: output is below potential, $Y_{1}=Y-\Delta Y$, and the representative consumer has no access to external credit in period 1 ( $L^{\prime}$ is equal to zero). 
The crisis state thus consists of both an output drop and a sudden stop in capital flows. As equation 4 shows, the negative impact of the fall in output and capital inflows on domestic consumption can be mitigated by running down reserves $\left(R^{\prime}=0\right) .{ }^{11}$ I shall assume, as a matter of normalization, that $Y=1$, so that the output cost of a crisis $\Delta Y$ and the size of the sudden stop $L$ are expressed in terms of potential output. I also assume that the desired level of consumption is equal to potential output $\left(C^{*}=Y\right)$ so that there is no predictable trade deficit in period 1.

The ex ante probability of a crisis is denoted by $\pi$. To capture the idea that reserves might provide a benefit in terms of prevention, I assume that the probability of crisis is a decreasing function of the ratio of reserves to short-term debt,

$$
\pi(R)=F\left(v-a \frac{R}{L}\right)
$$

where $F(\cdot)$ is an increasing function, and $v$ is a measure of vulnerability to a crisis, summarizing the fundamentals other than reserves. I will at times refer to the coefficient $a$ as the prevention benefit parameter. In calibrating the model I will use a probit specification, implying that $F($.$) is the cumu-$ lative distribution of a normal function.

The interesting question is how the optimal level of reserves $R$ depends on the relevant determinants: the country's vulnerability to a crisis, measured by $v$; the magnitude of the crisis, measured by the size of the shock to the capital account $L$ and of the output loss $\Delta Y$, and the opportunity cost of reserves, $\delta$.

\section{The Optimal Level of Reserves}

As shown in appendix B, the optimal level of reserves minimizes a loss function that equals the opportunity cost of reserves plus the expected welfare cost of a crisis:

$$
\text { Loss }=\delta R+\pi(R) f(R),
$$

11. Note that the consumer always repays the short-term debt that is not rolled over; that is, default is ruled out by assumption as a way of smoothing domestic consumption. 
Figure 6. Total Loss and the Optimal Level of Reserves

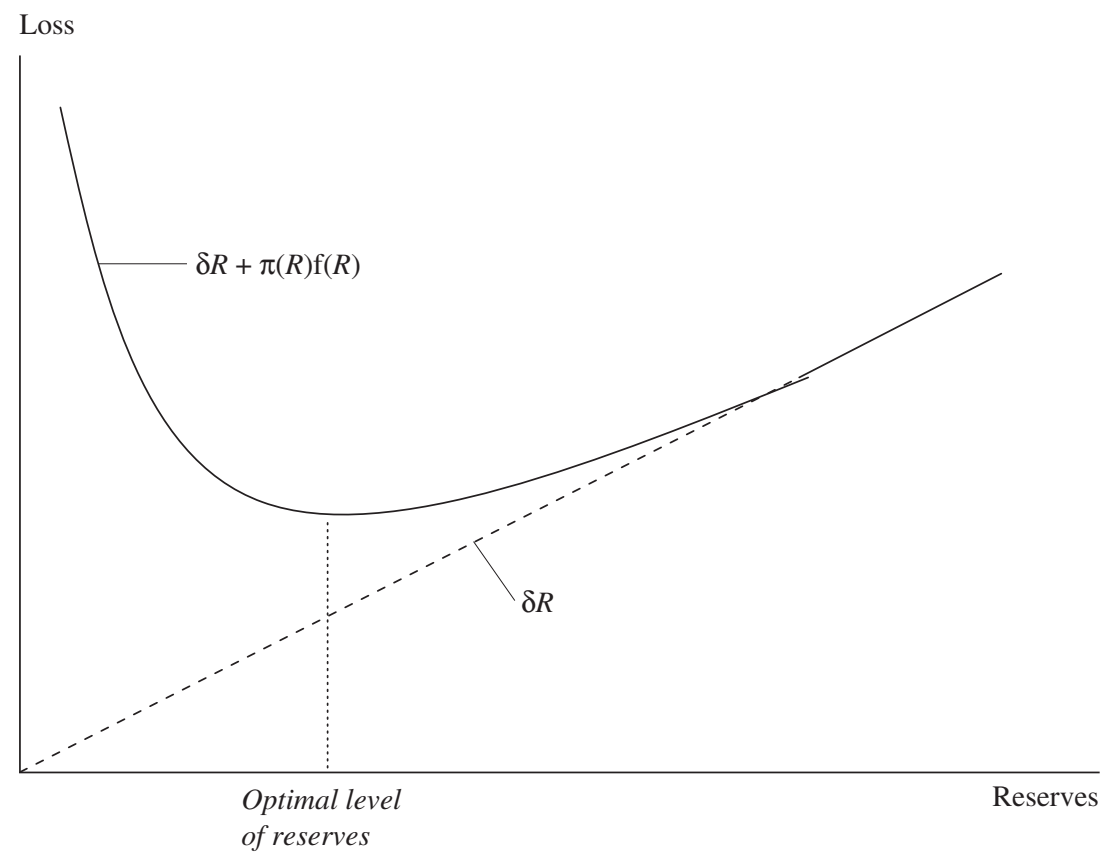

where $f(R)$, the welfare cost of a crisis, is increasing with the size of the crisis $(L$ and $\Delta Y)$ and decreasing with the level of reserves $R$.

Equation 7 is reminiscent of the loss function postulated in some earlier cost-benefit analyses of optimal reserves. ${ }^{12}$ It captures in a simple way the trade-off between the opportunity cost of reserves $\delta R$ and their benefits in terms of crisis prevention $\pi(R)$ and crisis mitigation $f(R)$. It can be interpreted, in a more dynamic context, as the average intertemporal loss of a country maintaining a constant level of reserves $R$. The consumer bears the opportunity $\operatorname{cost} \delta R$ in every period but pays the welfare cost of a crisis with a frequency $\pi(R)$. Equation 7 thus sums up the average cost of crises and the average cost of insuring against those crises. As shown in figure 6 , for low levels of reserves the gains from increasing reserves, in

12. See, for example, Heller (1966), Ben Bassat and Gottlieb (1992), and Garcia and Soto (2004). 
terms of crisis prevention and crisis mitigation, dominate the opportunity cost, whereas the opposite holds for high levels of reserves.

Closed-form expressions for the optimal level of reserves can be obtained if one assumes that reserves have no benefits in terms of preventionthat is, if $\pi$ is exogenous. The first-order condition for the minimization of the loss function in equation 7 can then be written as

$$
u^{\prime}\left[C^{*}-(\bar{R}-R)\right]=1+\frac{\delta}{\pi},
$$

where $\bar{R}=L+\Delta Y$ is the "full insurance" level of reserves, that is, the minimum level sufficient to maintain consumption at the desired level in a crisis. This condition implies that the optimal level of reserves is increasing with the probability of a crisis and decreasing with the opportunity cost of holding reserves-as one would expect.

If the consumer has constant relative risk aversion $\sigma$, then the optimal level of reserves is given by the formula

$$
R=L+\Delta Y-\left[1-\left(1+\frac{\delta}{\pi}\right)^{-1 / \sigma}\right]
$$

In words, the optimal level of reserves is equal to short-term external debt plus the output cost of a crisis minus a term reflecting the opportunity cost of holding reserves.

Note that in this model the optimal level of reserves could be higher than under the Greenspan-Guidotti rule $(R=L)$, because reserves smooth the impact on consumption of the fall in output, and not only the impact of the debt rollover crisis. The optimal level of reserves could also be lower than short-term debt because of the opportunity cost of holding reserves, which the Greenspan-Guidotti rule ignores.

The optimal level of reserves does not have a closed-form expression in the general case where the probability of a crisis is endogenous to the level of reserves. Then the optimal level of reserves minimizes

$$
\text { Loss }=\delta R+F\left(v-a \frac{R}{L}\right) f(R) .
$$

Taking into account the benefits of crisis prevention leads to an increase in the optimal level of reserves, other things equal. In fact-and this is 
an important difference from the case where the probability of a crisis is exogenous - the optimal level of reserves may now exceed the "full insurance" level $\bar{R}=L+\Delta Y$. Crisis prevention could make it optimal for a country to hold more reserves than it is willing to spend in a crisis.

\section{The Benefits of International Reserves}

I now turn to the calibration of the model, starting with the benefits of reserves. In my model reserves yield benefits in terms of crisis prevention $\pi(R)$ and crisis mitigation $f(R)$. To calibrate the model I thus try to identify each type of benefit in the data. ${ }^{13}$

\section{Crisis Prevention}

The international financial crises of the 1990s triggered a search for reserves adequacy ratios that would capture the vulnerability of emerging market countries' balance sheets and capital accounts in a world with highly mobile capital flows. The staff of the International Monetary Fund concluded that the ratio of reserves to short-term external debt was the "single most important indicator of reserves adequacy in countries with significant but uncertain access to capital markets," ${ }^{14}$ although this ratio should be taken as only a starting point for an analysis that should also look at other reserves adequacy ratios in light of each country's specific conditions. ${ }^{15}$

This view was supported by a vast body of empirical research showing that the ratio of reserves to short-term external debt tended to perform well as an early indicator of currency crises. By contrast, the (relatively

13. In line with the model, my discussion will focus on crisis management and will not deal with some benefits that reserves may have in noncrisis times, such as limiting exchange rate volatility (Hviding, Nowak, and Ricci, 2004) or providing liquidity to the foreign exchange market. Reserves can also yield benefits if the government is able to invest them more wisely than the average citizen, or if they promote capital market integration and domestic financial development.

14. $\operatorname{IMF}(2000$, p. 6).

15. Those conclusions were presented in two documents: "Debt- and Reserve-Related Indicators of External Vulnerability" (IMF, 2000) and "Issues in Reserves Adequacy and Management" (IMF, 2001). One study that contributed to crystallizing the official sector's conventional wisdom about the importance of this ratio was Bussière and Mulder (1999). See also Mulder (2000). 
smaller) empirical literature on sudden stops in capital flows has been less conclusive, generally failing to detect a significant preventive role for reserves. ${ }^{16}$

In order to take a broad view of the preventive role of reserves with respect to both currency crises and sudden stops, I ran a number of univariate probit regressions using various crisis definitions and reserves adequacy ratios. The regression results are based on four different definitions of a currency crisis (denoted by $\mathrm{CC} 1$ to $\mathrm{CC} 4$ ) and four different definitions of a sudden stop (denoted by SS1 to SS4). Appendix table A-2 gives these definitions, and table A-3 lists the years when each type of crisis occurred in each country. For the first of the currency crisis definitions (CC1), I use Frankel and Rose's criterion of a nominal depreciation of the currency of at least 25 percent relative to the previous year that is also at least a 10-percentage-point increase in the rate of depreciation. ${ }^{17}$ The other three definitions ( $\mathrm{CC} 2$ to $\mathrm{CC} 4)$ are based on a crisis pressure index that adds the percentage nominal depreciation of the currency to the percentage loss in foreign reserves. ${ }^{18}$

I first identify sudden stops as those years in which net capital inflows fell by more than 5 percent of GDP (SS1). This simple criterion has been criticized for various reasons, in particular because it captures some episodes in which capital net inflows slowed down but remained positive (such as Malaysia in 1994, following the imposition of controls on capital inflows). For robustness, I also consider three sudden stop measures that are more stringent (SS2 to SS4). ${ }^{19}$

16. The literature on early warning signals and the empirical determinants of crisis in probit/logit regressions is too large to be reviewed here-the reader is referred to the reviews by Kaminsky, Lizondo, and Reinhart (1998), Berg, Borensztein, and Pattillo (2005), and Frankel and Wei (2005). Another way in which reserves might stabilize the domestic economy is by lowering the interest rate on foreign debt (Levy Yeyati, 2006). Evidence that larger reserves decrease the sovereign spread is provided in Hauner (2005), Duffie, Pedersen, and Singleton (2003), and Eichengreen and Mody (2000). By contrast with currency crises, Calvo, Izquierdo, and Mejía (2004) and Frankel and Cavallo (2004) did not find that reserves had a statistically significant effect of reducing the probability of sudden stops.

17. Frankel and Rose (1996).

18. Frankel and Wei (2005).

19. The precise definitions are given in table A-2 in appendix A. The crisis dates for SS2 to SS4 are taken from Frankel and Cavallo (2004), who apply the criteria of Calvo, Izquierdo, and Mejía (2004) to a larger sample of countries and a longer time period. 
Table 2. Regressions of Crisis Variables on Alternative Measures of Reserves, 1980-2000

No. of regressions achieving statistical significance ${ }^{\mathrm{a}}$

\begin{tabular}{lcc}
\hline & \multicolumn{2}{c}{ Dependent variable (type of crisis) } \\
\cline { 2 - 3 } Measure of reserves adequacy & Currency crisis & Sudden stop \\
\hline Ratio of reserves to imports & 9 & 1 \\
Ratio of reserves to short-term debt & 16 & 0 \\
$\quad$ World Bank measure) & 4 & 1 \\
Ratio of reserves to short-term debt (BIS measure) & 0 & 4 \\
Ratio of reserves to M2 & 12 & 1 \\
Ratio of reserves to GDP & & \\
\hline
\end{tabular}

Source: Author's calculations.

a. For each pair of reserves adequacy measure and type of crisis, regressions were performed combining each of four crisis definitions with one of four fixed-effects specifications (no fixed effects, country fixed effects only, time fixed effects only, and both country and time fixed effects), for a total of sixteen regressions. Each cell of the table reports the number of regressions out of the sixteen in which the coefficient on the indicated reserves adequacy ratio was negative and significant at the 10 percent level or better.

Table 2 summarizes the results of 160 univariate regressions using various reserves adequacy ratios, crisis definitions, and probit specifications. For each crisis definition and reserves adequacy ratio, I ran four probit regressions of the crisis dummy variable on the lagged reserves ratio and a constant: without fixed effects, with country fixed effects, with time fixed effects, and with both country and time fixed effects. Since currency crises and sudden stops each have four different definitions, each cell in the table is based on sixteen probit regressions. The table reports the number of regressions in which the coefficient on reserves was both negative and significant at the 10 percent level or better.

Several facts stand out. First, the denominator of the reserves adequacy ratio that "works" best to predict a currency crisis is short-term debt. ${ }^{20}$ The benefit of increasing reserves in terms of crisis prevention, furthermore, is economically significant. To illustrate, figure 7 shows how the probability of a crisis varies with the Greenspan-Guidotti ratio

20. More precisely, the measure of short-term debt that works best is that from the World Bank Global Development Finance database rather than that in the Bank for International Settlements (BIS) data. This result is surprising because the BIS data should be a better measure of the denominator in the Greenspan-Guidotti ratio (the BIS reports debt maturing in the following year, whereas the World Bank data are based on maturity at issuance). However, the BIS debt measure might be less significant because it is available for fewer of the countries in the regressions. 
Figure 7. Reserves and Crisis Prevention ${ }^{\mathrm{a}}$

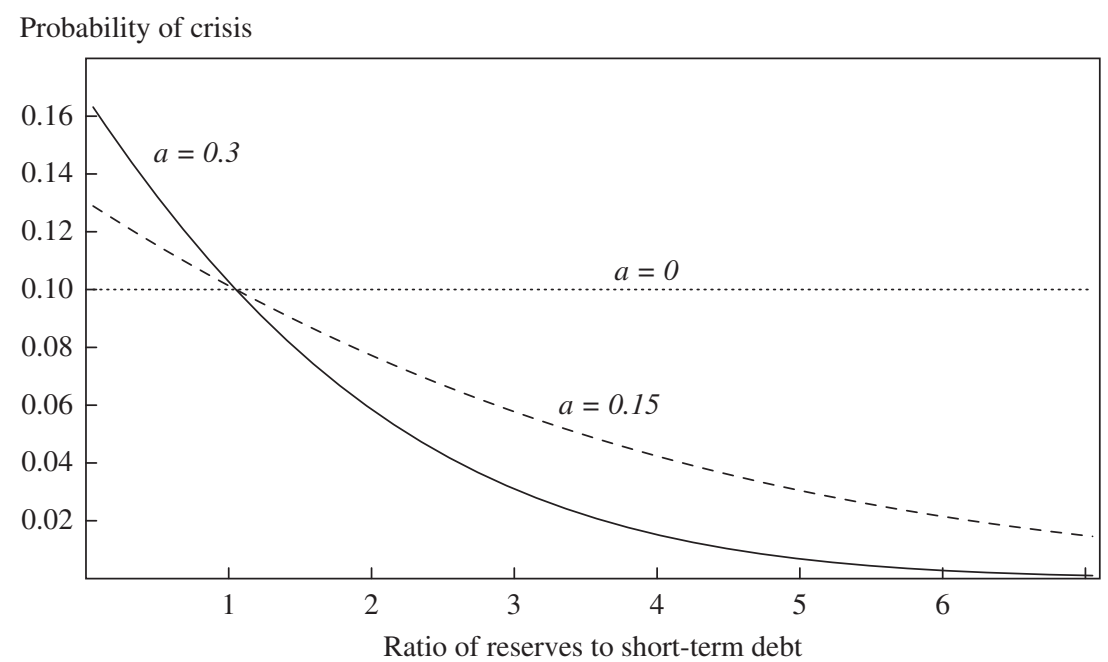

Sources: Author's calculations.

a. The variable $a$ is the prevention benefit parameter, the coefficient on the Greenspan-Guidotti ratio in the crisis probability function (equation 6 in the text). It is assumed that the probability of crisis is 10 percent for $R=L$.

$R / L$ for values of $a$ in the range of estimation of the probit. As the figure shows, if $a=0.3$, doubling the ratio of reserves to short-term debt from 1 to 2 reduces the probability of a crisis by almost 4 percentage points. However, there are diminishing returns to further increasing reserves: increasing $R / L$ from 5 to 6 reduces the probability of crisis by less than 1 percent.

Second, the reserves adequacy ratios do not perform as well at predicting sudden stops as they do at predicting currency crises. The ratio that works best is that based on M2, but even this ratio is significant in only one-fourth of the regressions. This result also seems consistent with the empirical literature, which is ambiguous with regard to the benefits of reserves in preventing sudden stops rather than currency crises.

One important caveat is necessary before one accepts the conclusion that reserves help to prevent crises. The existing empirical studies do not really distinguish between two possibilities: whether high levels of reserves allow countries to prevent crises, or whether spending the reserves merely 
postpones the crises. ${ }^{21}$ This identification problem does not affect the rationale for using reserves as an early warning indicator of crisis, but it may lead to an exaggeration of the benefits of reserves in terms of crisis prevention. In many cases, countries might actually have hastened the crisis, and not reduced its probability, by trying to maintain a high level of reserves in the face of a loss of confidence in domestic policies.

\section{Crisis Mitigation}

There are two ways in which reserves can help to mitigate the impact of a balance of payments crisis on domestic welfare. First, the reserves can be used to mitigate the fall in domestic output. Second, the reserves can be used to buffer the impact of the balance of payments shock on domestic absorption.

The authorities can reduce the output cost of a crisis by using international reserves through various channels. Foreign exchange interventions can mitigate the depreciation of the domestic currency, and thus the disruption induced by currency mismatches in balance sheets. Reserves help the monetary authorities in providing liquidity to the domestic financial markets, the banking sector, and even exporters; this is especially valuable if there is significant dollarization of bank deposits and other domestic liabilities. $^{22}$

As for the second benefit, I present a simple accounting exercise that shows the extent to which international reserves help smooth domestic absorption in the face of balance of payments shocks. In a small, open

21. This ambiguity is certainly present in the theoretical literature on crises and reserves. In some models, a large volume of reserves effectively reduces the probability of crisis by making the economy more resilient to adverse shocks (Chang and Velasco, 2000; Aizenman and Lee, 2005) or to self-fulfilling changes in market sentiment (Morris and Shin, 1998). By contrast, in the Krugman-Flood-Garber framework, a speculative attack made unavoidable by excessive money growth is merely delayed by a larger stock of reserves (Krugman, 1979; Flood and Garber, 1984). In addition, countries often shorten the maturity of their debt before a crisis, further reducing the Greenspan-Guidotti ratio (Detragiache and Spilimbergo, 2001).

22. Jeanne and Wyplosz (2003) and Calvo (2006) emphasize that lending the reserves to domestic agents is a more effective tool than foreign exchange intervention in preventing and mitigating crises. Calvo (2006) points to an interesting example of a nonstandard way of disposing of international reserves: in August 2002 the central bank of Brazil employed some of its international reserves to make loans to the export sector through commercial banks. 
economy, domestic absorption can be written as the sum of domestic output, capital inflows, and reserves decumulation (net income from abroad is omitted because it typically varies little in a crisis): ${ }^{23}$

$$
A_{t}=Y_{t}+K A_{t}-\Delta R_{t}
$$

There is an exact correspondence between this decomposition and equation 4 of the model, which can be written

$$
C_{1}=Y_{1}+\underbrace{\left(L^{\prime}-L\right)}_{K A}-\underbrace{\left(R^{\prime}-R\right)}_{\Delta R} .
$$

Thus information about the behavior of the components of equation 11 can help in calibrating the model. I now look at how the components of equation 11 behave in observed sudden stop episodes. Sudden stops will be identified, in my sample of emerging market countries, as a year in which net capital inflows fall by more than 5 percent of GDP (definition SS1).

Figure 8 shows the average behavior of domestic absorption and the contribution of the various components on the right-hand side of equation 11 in a five-year event window centered around a sudden stop. Real output is normalized to 100 in the year before the sudden stop. All the variables are converted from current dollars into constant local currency units so that the changes in output and domestic absorption can be tracked in volume terms. ${ }^{24}$

A large fall in net capital inflows is observed in the year of the sudden stop, amounting to almost 10 percent of the previous year's output on average. This is not surprising, since a large fall in those inflows is the criterion used to identify sudden stops. More interestingly, most of the negative impact of the capital account reversal on domestic absorption is offset

23. See Jeanne and Rancière (2006). This decomposition of domestic absorption results from two national accounting identities. First, domestic absorption (the sum of domestic private and public consumption and investment) is the difference between real output and the trade balance, $A_{t}=Y_{t}-T B_{t}$. Second, the balance of payments equation $C A_{t}=K A_{t}+\Delta R_{t}$, where $C A_{t}=T B_{t}+I T_{t}$ is the current account balance (the sum of the trade balance and income and transfer from abroad), can be used to substitute out the trade balance from the first identity.

24. The dollar value of output and domestic absorption falls by a larger amount than indicated in figure 8 because of the real depreciation of the domestic currency. The variables are converted from current dollars to constant local currency units using the nominal dollar exchange rate and the local GDP deflator. IMF loans are counted as a loss of reserves rather than as capital inflows. 
Figure 8. Domestic Absorption, Output, Net Capital Inflows, and Reserves in Sudden Stops ${ }^{\mathrm{a}}$

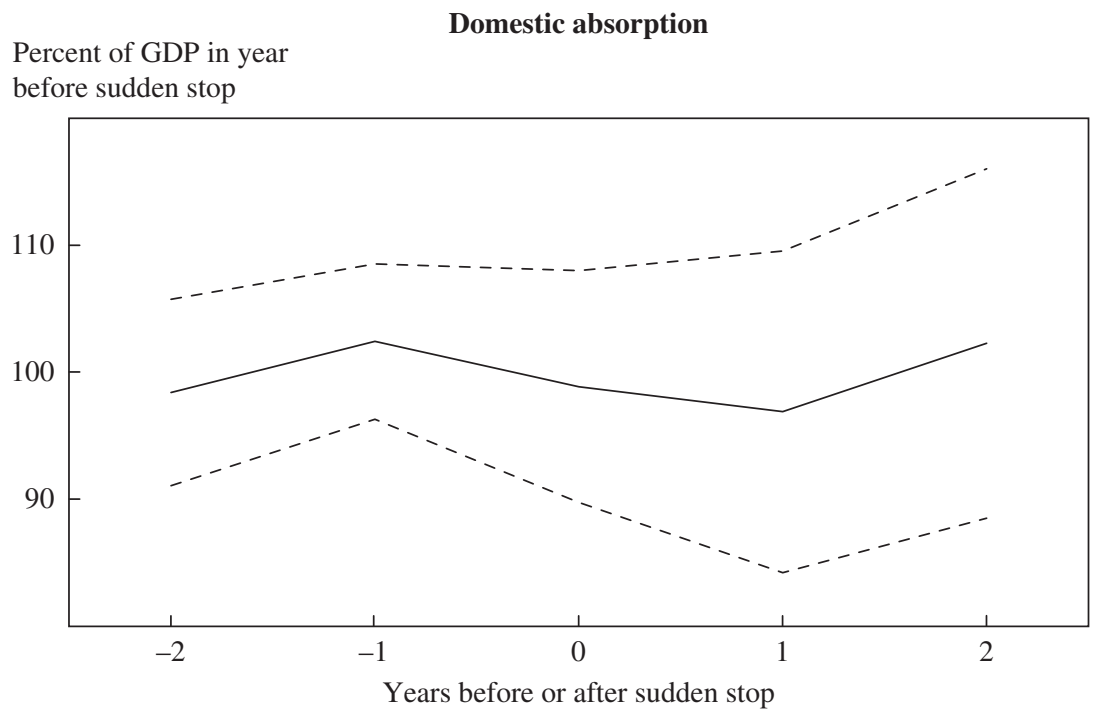

Domestic output

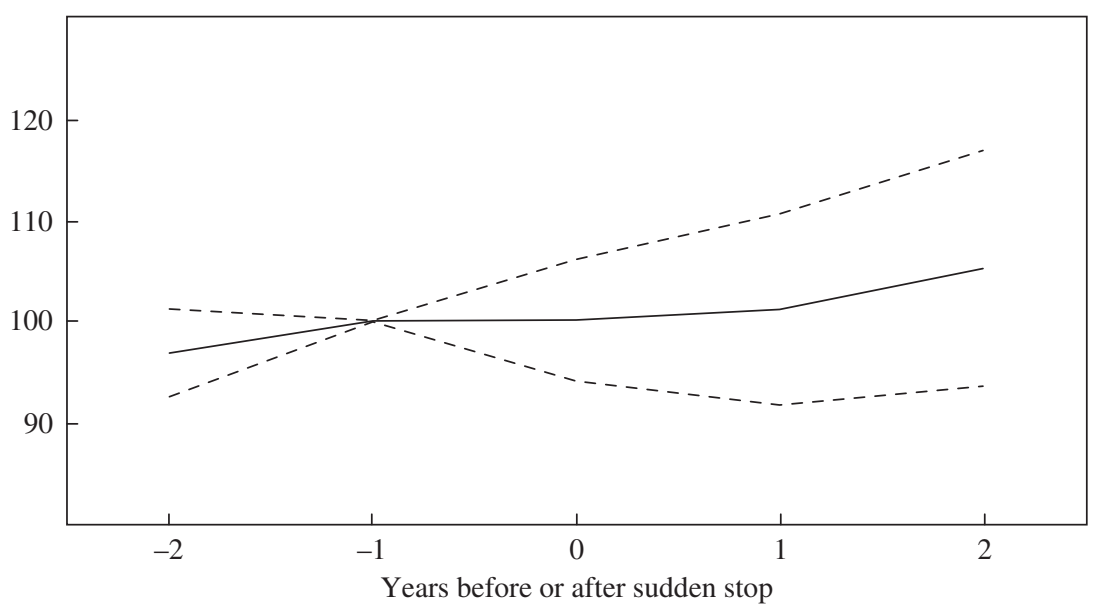

(continued) 
Figure 8. Domestic Absorption, Output, Net Capital Inflows, and Reserves in Sudden Stops ${ }^{\text {a }}$ (Continued)

Percent of GDP in year

\section{Net capital inflows}

before sudden stop

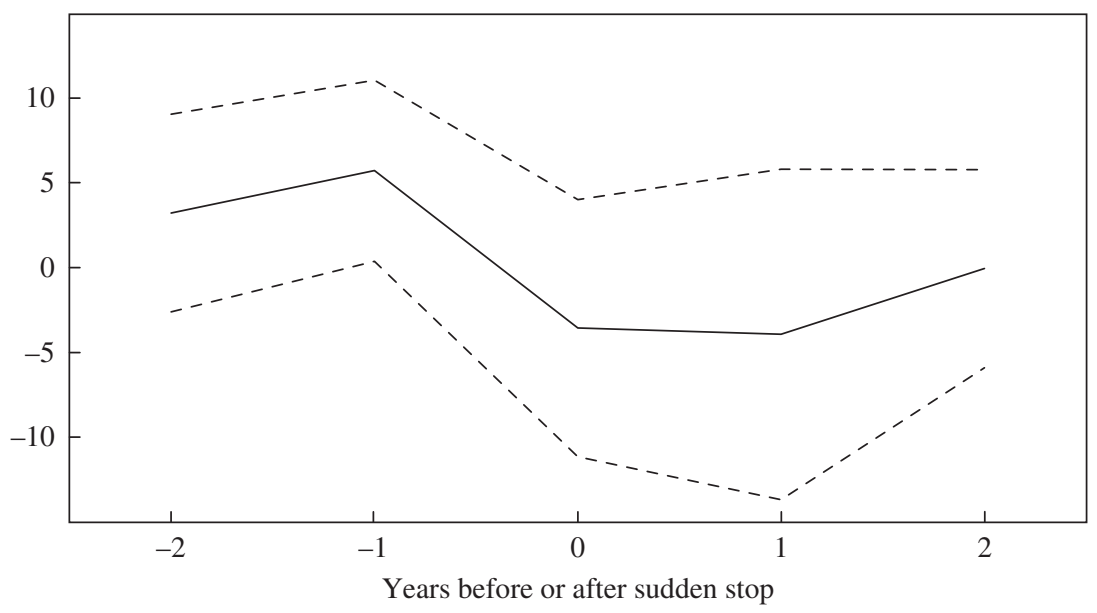

Decrease in reserves

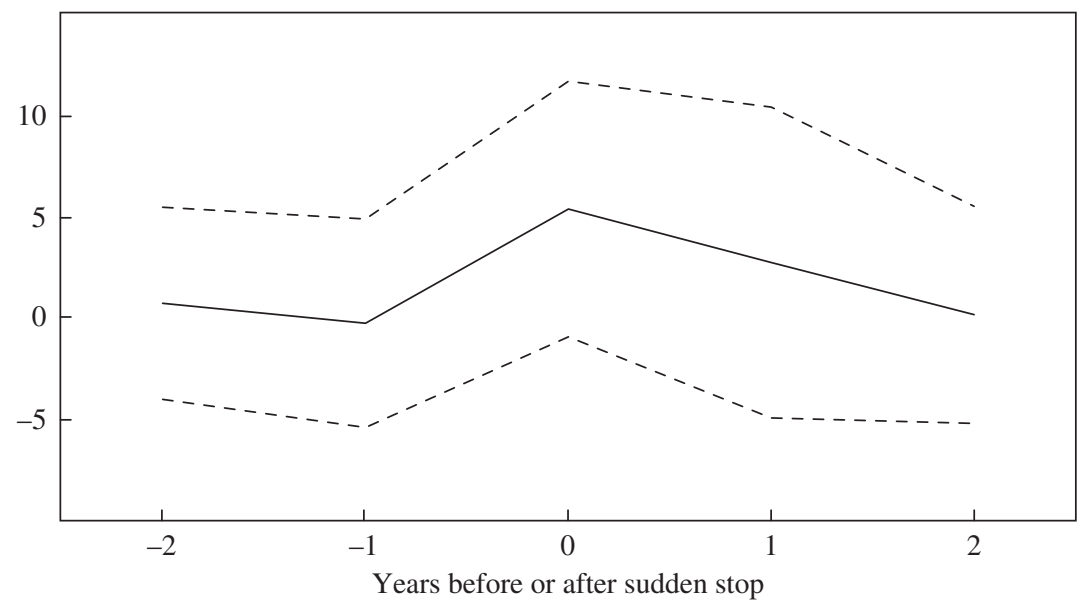

Sources: Author's calculations using data from the IMF, International Financial Statistics, and the World Bank, World Development Indicators.

a. A sudden stop is defined as a fall in the financial account of more than 5 percent of GDP (SS1). Events that occurred before 1980 or within the five-year window of a previous sudden stop are excluded from the calculation. The solid line is the sample mean; dotted lines indicate the mean plus and minus one standard deviation. 
by a fall in reserves accumulation. Thus domestic absorption falls by only 3 percent of GDP on average in the year of the sudden stop-much less than the capital inflows. Figure 8 also shows that the contribution of output to the decline in domestic absorption is relatively small: real growth merely falls to zero at the time of the sudden stop.

This evidence is consistent with the view that emerging market countries accumulate reserves in good times so as to be able to decumulate them, thereby smoothing domestic absorption, in response to sudden stops. This smoothing effect is potentially large. To illustrate, if reserves accumulation were equal to zero in the year of the sudden stop, domestic absorption would fall by 9 percent of output on average instead of 3 percent, other things equal. This counterfactual experiment should be interpreted with caution, because the magnitude of capital flight could in part be endogenous to the fall in reserves. It does suggest, however, that foreign exchange reserves may well make a sizable contribution to the smoothing of domestic absorption in response to sudden stops.

The case of Uruguay in 2002 provides a striking illustration of the role of reserves in a very severe sudden stop episode. Following the Argentine crisis, net capital inflows to Uruguay fell by 26 percentage points of precrisis GDP. The Uruguayan government used a large amount of foreign exchange reserves (a significant part of which was made available in the context of an IMF arrangement) to cover the withdrawal of dollar-denominated deposits from the domestic banking system. As a result, the decline in domestic absorption, although quite substantial (14 percent of GDP), was much smaller than the shock to the capital account.

\section{The Costs of International Reserves}

The cost of holding reserves is measured in the literature-as in the model - as the difference between the return on the reserves and the return on more profitable alternative investment opportunities. ${ }^{25}$ One term of the

25. My discussion focuses on the opportunity cost of carrying the reserves and does not deal with the challenges to monetary and financial stability posed by large-scale sterilization (see Mohanty and Turner, 2006, and European Central Bank, 2006, for a discussion of those costs). Another cost that I do not discuss is the false sense of confidence that reserves may instill in foreign investors, allowing the domestic authorities to postpone necessary adjustments. Finally, large-scale purchases and sales of reserves could induce exchange rate changes that cause valuation losses on the reserves. 
comparison, the return on the reserves, is generally proxied as the return on short-term foreign currency assets. The appropriate definition of alternative investment opportunities, on the other hand, raises several thorny questions.

One approach is to consider higher-yielding investment opportunities in the domestic business sector or in the building of public infrastructure. However, the marginal product of capital is difficult to measure in a way that is comparable across a large number of countries. Caselli and Feyrer's recent estimates can be used to compute an average annual real return to capital of 7.8 percent in seventeen emerging market countries in my sample. ${ }^{26}$ This, together with an estimate for the short-term real interest rate of 2 percent a year-roughly the average U.S. real short-term rate over 1980-2005-would lead to an opportunity cost of around 6 percent a year.

Given the difficulties involved in measuring the returns to physical investment, most measures in the literature assume that the alternative to holding international reserves is to invest in other financial assets or to repay existing financial liabilities. One approach defines the opportunity cost of reserves as the quasi-fiscal cost of sterilization by the central bank, that is, the difference between the return on the central bank's domestic currency assets and the return on international reserves. ${ }^{27}$ This differential is generally positive, but in countries where domestic interest rates are very low-such as China recently - this approach leads to a negative opportunity cost of reserves.

There are two serious issues with measuring the opportunity cost of reserves in this way. First, this measure is not adjusted for the expected appreciation or depreciation of the domestic currency. For example, the fiscal cost of reserves could be found to be negative because the domestic currency is expected to appreciate relative to the dollar-and interest rate parity applies-but this measure fails to take into account the expected valuation loss on the reserves. Second, the central bank's profit is not a measure of domestic welfare. Selling high-yielding domestic bonds for reserves may reduce the central bank's flow of profit but increases the income of the domestic investors who purchase the bonds. The opportu-

26. Caselli (2007) computes the return to capital using production functions calibrated as in the development accounting literature. They find that the return to capital is not higher in developing countries than in industrial countries once one adjusts for nonreproducible capital (land).

27. See, for example, Frenkel and Jovanovic (1981), Flood and Marion (2002), and Mohanty and Turner (2006). 
Figure 9. Alternative Measures of the Opportunity Cost of Reserves, 2000-05 ${ }^{\mathrm{a}}$

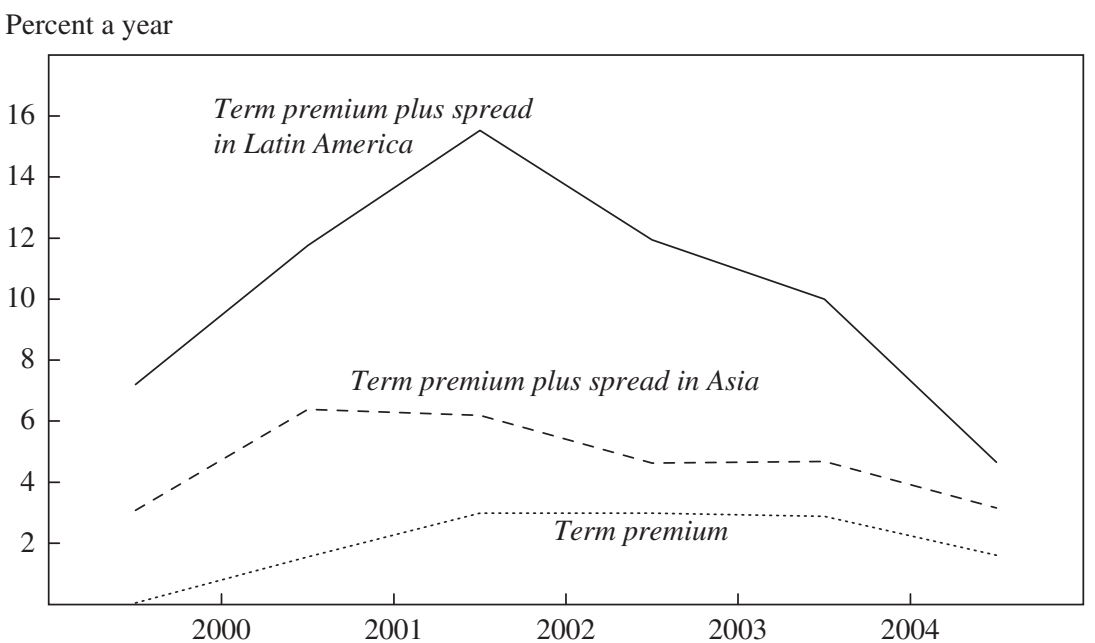

Sources: Author's calculations using data from Bloomberg and IMF, International Financial Statistics.

a. The term premium is the difference between the return on long-term dollar assets and liquid dollar assets. The spread is the difference between the interest rate on external debt and the return on reserves.

nity cost of reserves should therefore be measured by looking at the budget of the country as a whole rather than that of the central bank. This might be a reason to measure the opportunity cost of reserves by reference to external_-rather than domestic_-assets and liabilities.

Reserves can be accumulated by issuing-or can be used to repayexternal debt. Given this observation, some authors measure the opportunity cost as the spread between the interest rate on external debt and the return on reserves. ${ }^{28}$ By this measure the opportunity cost of reserves was 8.4 percent a year in emerging market countries on average in 2000-05, but this figure masks important disparities between Asia, where the spreads were low, and Latin America, where they were much higher (figure 9).

One might argue that these spreads overstate the true opportunity cost of holding reserves, because they include the default risk premium on foreign debt. As shown more formally in appendix B, the welfare-based

28. This measure was initially proposed by Edwards (1985). It is used by Garcia and Soto (2004) and Rodrik (2006). 
Table 3. Average Annual Cost of Holding Reserves, 2000-05

Percent of GDP

\begin{tabular}{lccc}
\hline Assumption & $\begin{array}{c}\text { All emerging } \\
\text { markets }\end{array}$ & Asia & $\begin{array}{c}\text { Latin } \\
\text { America }\end{array}$ \\
\hline $\begin{array}{l}\text { Opportunity cost of reserves is 6 percent a year } \\
\begin{array}{l}\text { Opportunity cost of reserves is the term premium } \\
\quad \text { (2 percent a year) }\end{array}\end{array}$ & 0.93 & 1.29 & 0.65 \\
$\begin{array}{l}\text { Opportunity cost of reserves is the term premium } \\
\text { plus the spread on external debt }\end{array}$ & 0.32 & 0.45 & 0.22 \\
\hline
\end{tabular}

Source: Author's calculations using data from Bloomberg; World Bank, World Development Indicators; and International Monetary Fund, International Financial Statistics.

a. The sample includes all the emerging market countries listed in appendix table A-1, except Korea and India. Data are unweighted averages for the countries in each group. The term premium is the difference between the return on long-term dollar assets and liquid dollar assets. The spread is the difference between the interest rate on external debt and the return on reserves.

approach suggests that the default risk premium should not be included, because it is, on average, a fair reflection of the probability of less than full repayment. Pushed to its logical extreme, this approach suggests that the true opportunity cost of reserves is the U.S. term premium, that is, the opportunity cost of financing a stock of liquid dollar assets with defaultfree long-term dollar debt. This would lead to a much lower measure of the opportunity cost of reserves of at most 2.5 percent. ${ }^{29}$

Table 3 presents some measures of the average opportunity cost of reserves in terms of domestic GDP in my sample of emerging market countries over the period 2000-05. The measures are based on a uniform opportunity cost of 6 percent as well as the term premium, with and without a spread. With an opportunity cost of 6 percent a year, the average cost of reserves amounts to 1 percent of GDP..$^{30}$ The estimated cost of reserves is significantly lower if one considers the term premium, but larger if one includes the emerging market spread. On average, the total cost of holding reserves was substantially lower in Latin America than in Asia if one uses the same opportunity cost per unit of reserves for both regions, but it was relatively similar in the two regions when one uses the term premium plus the spread. This is explained by the fact that, whereas on average the

29. The differential between ten-year U.S. Treasury bonds and three-month U.S. Treasury bills was almost 2.5 percentage points on average over 2000-05. Expectation-adjusted measures lead to even lower estimates of less than 1 percentage point (Rudebusch, Sack, and Swanson, 2007).

30. This is consistent with the estimates obtained by Rodrik (2006) and Bird and Rajan (2003). 
Table 4. Benchmark Calibration Parameters

\begin{tabular}{lll}
\hline Parameter & Baseline & Range \\
\hline Size of sudden stop & $L=0.1$ & {$[0,0.3]$} \\
Probability of sudden stop & $\pi=0.1$ & {$[0,0.25]$} \\
Output loss & $\Delta Y=0.1$ & {$[0,0.2]$} \\
Opportunity cost & $\delta=0.03$ & {$[0.01,0.06]$} \\
Risk aversion & $\sigma=2$ & {$[1,10]$} \\
Prevention benefit parameter & $a=0$ & {$[0,0.3]$} \\
\hline
\end{tabular}

reserves-GDP ratio is more than twice as high for Asian countries as for Latin American countries, the sovereign spread is substantially higher in Latin America than in Asia.

\section{Model Predictions}

The model presented above is used here to predict the optimal level of reserves in emerging market countries. This is done in two steps. First, I calibrate the model by reference to an average emerging market country, as a way of getting a broad sense of the quantitative implications of the model and their sensitivity to the parameters chosen. Second, I calibrate the model by reference to country-specific data, to study how far the model can go in explaining the reserves buildup in emerging market countries.

\section{Benchmark Calibration and Sensitivity Analysis}

The benchmark calibration is based on the parameter values given in table 4. I assume that reserves provide no benefits in terms of prevention, so that the formula in equation 9 applies. The probability of crisis was set to the unconditional frequency of sudden stops (SS1) in my sample of emerging market countries, which is close to 10 percent a year. The value for the opportunity cost of reserves, $\delta=3$ percent, is close to the middle of the range of estimates discussed earlier. The chosen values for risk aversion and its range of variation are standard in the growth and real business cycle literature.

Capital flight $(L)$ and the output loss $(\Delta Y)$ are both set to 10 percent of GDP. These figures are in line with the behavior of capital flows and of 
output during the sudden stops documented in figure $8 .{ }^{31}$ The output cost figure was obtained by cumulating the average output gap in the year of a sudden stop and the following year, under the assumption that output would have grown at the same rate as before the crisis in the absence of a sudden stop. An output loss of 10 percent of GDP is in the ballpark of the estimates reported in the literature on currency crises and sudden stops. ${ }^{32}$

The benchmark calibration implies an optimal level of reserves of 7.7 percent of GDP, or 77 percent of short-term external debt. This is close to the ratio of reserves to GDP observed in the data on average over 1980-2000, but significantly below the level observed in the most recent period, especially in Asia. It would be interesting to know what changes in the parameters are required to increase the optimal level of reserves to something approaching the recently observed level.

Figure 10 shows the sensitivity of the optimal level of reserves to the probability of crisis, the opportunity cost of reserves, the degree of risk aversion, and the elasticity of the crisis probability to the level of reserves. In each case the level of reserves computed using the sudden stop model is contrasted with that implied by the Greenspan-Guidotti rule. Several interesting results emerge.

The optimal level of reserves is quite sensitive to the probability of crisis, the opportunity cost of reserves, and the risk aversion parameter. This offers an interesting contrast with the Greenspan-Guidotti rule, which does not depend at all on these parameters. The optimal level of reserves is zero if the probability of crisis falls below 5 percent, but it almost doubles, from 7.7 percent to 13.3 percent of GDP, if the probability of crisis increases from 10 percent to 20 percent. Risk aversion also has a firstorder impact on the optimal level of reserves. A shift in the risk aversion

31. Using instead the ratio of short-term external debt to GDP would give similar values for $L$. For my sample this ratio is 8.2 percent on average over the period 1980-2000 according to the World Bank's Global Development Finance (GDF) data set, and 11.7 percent according to the BIS database.

32. Hutchison and Noy (2006) find that the cumulative output loss of a sudden stop is around 13 to 15 percent of GDP over a three-year period. Becker and Mauro (2006) find an expected output cost of 10.2 percent of GDP for currency crises and 16.5 percent of GDP for sudden stops. On one hand, the estimated output cost of a crisis can be significantly larger if the output gap is cumulated until output has returned to potential, which typically takes longer than two or three years. On the other hand, using the precrisis growth rate to estimate postcrisis potential output may exaggerate the size of the output gap if the crisis was preceded by an unsustainable economic boom. 
Figure 10. Sensitivity of the Optimal Level of Reserves to Changes in Model Parameters ${ }^{\mathrm{a}}$

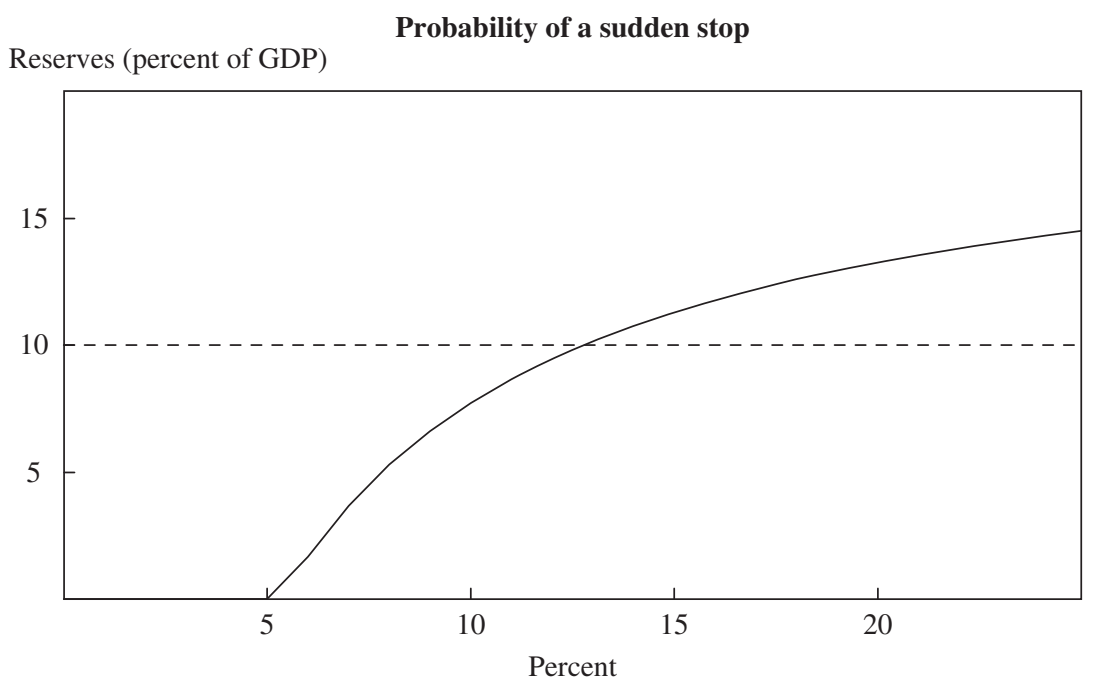

Opportunity cost of holding reserves

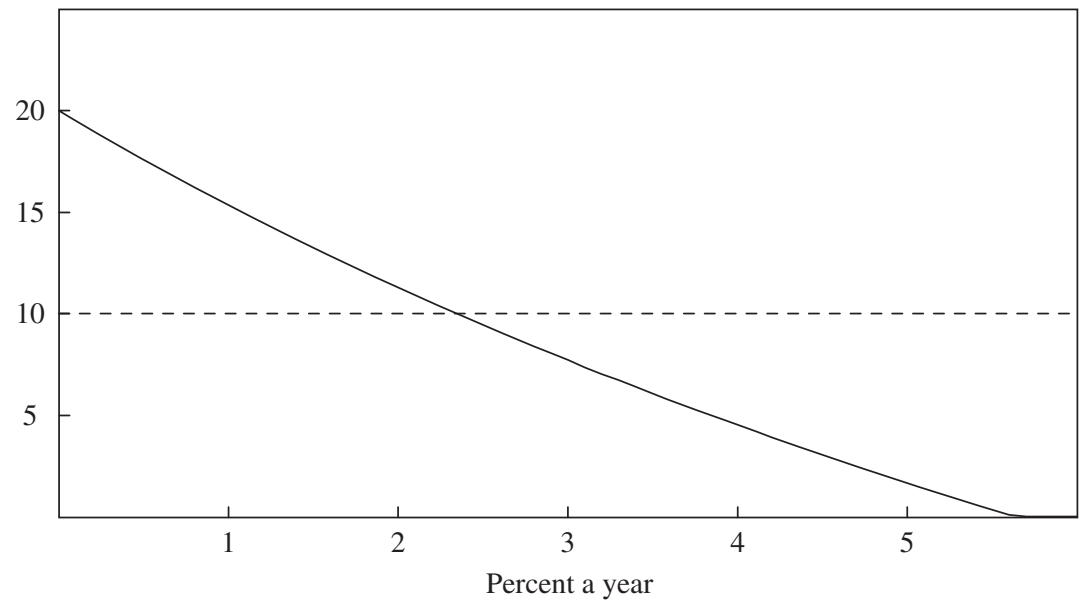

(continued) 
Figure 10. Sensitivity of the Optimal Level of Reserves to Changes in Model Parameters ${ }^{\mathrm{a}}$ (Continued)

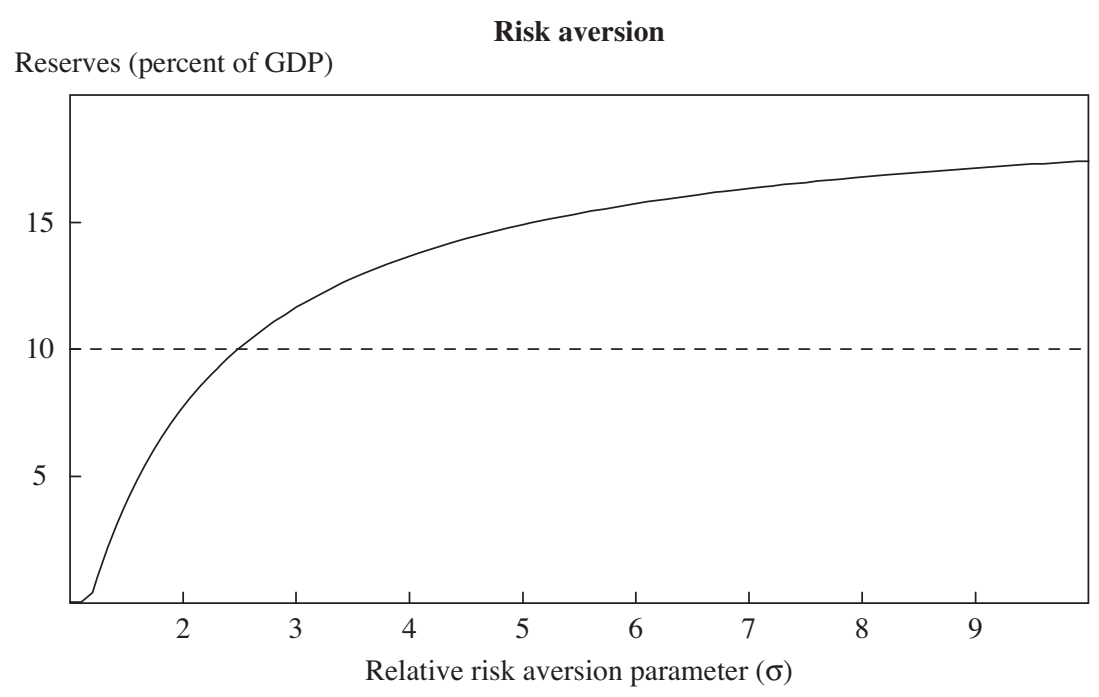

Prevention benefit

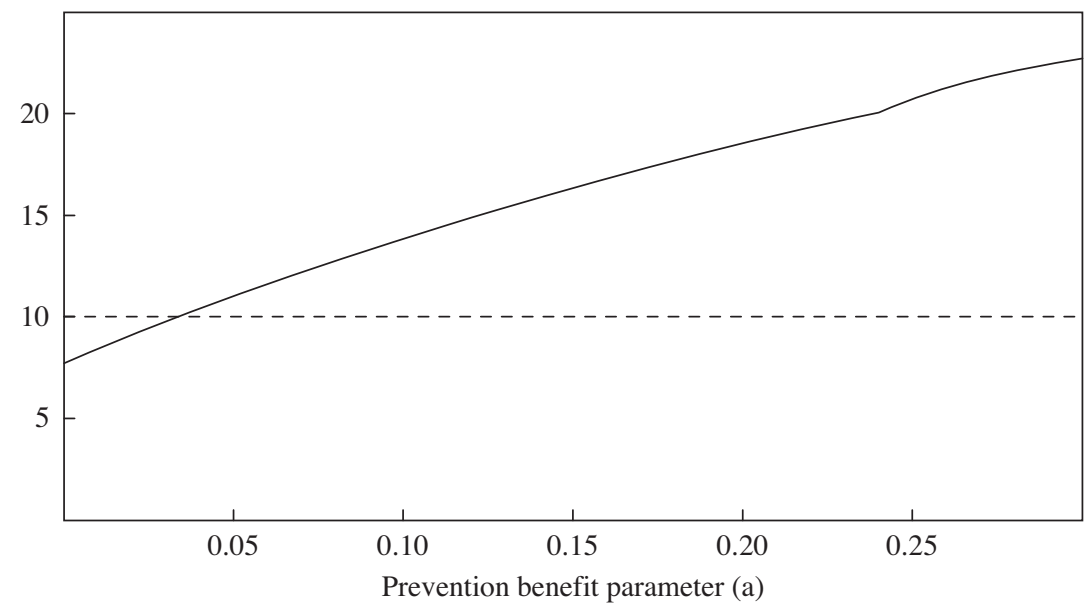

Sources: Author's calculations.

a. Dashed line indicates the optimal level of reserves using the Greenspan-Guidotti rule, assuming that short-term debt is 10 percent of GDP. 
parameter from 2 to 8 increases the optimal level of reserves from 7.7 percent to 16.8 percent of GDP.

Figure 10 also shows that the optimal level of reserves can be significantly larger if one assumes that reserves have benefits in terms of crisis prevention (parameter $a$ ). If, in line with my univariate probit results for currency crises, $a$ is set between 0.2 and 0.3 , then the optimal level of reserves can reach 23 percent of GDP, about three times the optimal level if reserves have no effectiveness at crisis prevention.

To summarize, there are two ways in which the model can potentially explain a level of reserves of the order of magnitude currently observed in Asia. The first is to assume very large numbers for capital flight or for the output cost of a crisis. To illustrate, if the size of the sudden stop or the output cost amounted to 40 percent of GDP, instead of 10 percent in the benchmark calibration, the model would predict an optimal level of reserves in excess of 35 percent of GDP. Such an assumption, however, seems out of line with the historical record on currency crises and sudden stops. The second and perhaps more plausible way in which the model can predict a higher level of reserves is if reserves offer substantial benefits in terms of crisis prevention.

\section{Country Estimates}

I now bring the model closer to the data by estimating the optimal level of reserves for each emerging market country in my sample in 2000. For each country I estimate the level of reserves that minimizes the loss function in equation 10, that is, the sum of the opportunity cost of reserves and of the expected welfare cost of a crisis,

$$
\operatorname{Loss}_{i}=\delta R_{i}+F\left(v_{i}-a \frac{R_{i}}{L_{i}}\right) f\left(R_{i}\right),
$$

where $i$ is the country index. This loss function is calibrated based on a probit estimation of the crisis probability for each country. The model indicates excess or insufficient reserves, depending on how the optimal level of reserves, $R_{i}^{*}$, compares with the observed level, $R_{i}$.

The first step is to estimate the probability of a crisis for each country. This is done by running a probit regression of the probability of crisis on the countries' economic fundamentals in my sample of emerging market 
Table 5. Probit Regressions of the Probability of Crisis on Macroeconomic Fundamentals, 1980-2000 ${ }^{\mathrm{a}}$

\begin{tabular}{|c|c|c|c|c|}
\hline \multirow[b]{2}{*}{$\begin{array}{l}\text { Type of crisis and } \\
\text { independent variable }\end{array}$} & \multicolumn{4}{|c|}{ Regression specification } \\
\hline & None & $\begin{array}{c}\text { Country } \\
\text { effects } \\
\text { only }\end{array}$ & $\begin{array}{l}\text { Year } \\
\text { effects } \\
\text { only }\end{array}$ & $\begin{array}{c}\text { Country } \\
\text { and year } \\
\text { effects }\end{array}$ \\
\hline \multicolumn{5}{|l|}{ Crisis is sudden stop SS $1^{\mathrm{b}}$} \\
\hline $\begin{array}{l}\text { Real exchange rate deviation from } \\
\text { Hodrick-Prescott trend }\end{array}$ & $\begin{array}{l}-1.240 * * * \\
(0.438)\end{array}$ & $\begin{array}{l}-1.295^{* *} \\
(0.521)\end{array}$ & $\begin{array}{l}-1.102 * * \\
(0.442)\end{array}$ & $\begin{array}{l}-1.192 * * \\
(0.519)\end{array}$ \\
\hline GDP growth ${ }^{c}$ & $\begin{array}{l}-2.047 * * * \\
(0.749)\end{array}$ & $\begin{array}{l}-2.028^{* *} \\
(0.830)\end{array}$ & $\begin{array}{l}-2.511 * * * \\
(0.884)\end{array}$ & $\begin{array}{l}-2.856 * * * \\
(1.038)\end{array}$ \\
\hline Ratio of foreign liabilities to money ${ }^{\mathrm{d}}$ & $\begin{array}{l}0.025^{* * * *} \\
(0.008)\end{array}$ & $\begin{array}{l}0.031^{* *} \\
(0.014)\end{array}$ & $\begin{array}{l}0.028^{* * *} \\
(0.008)\end{array}$ & $\begin{array}{l}0.037 * * * \\
(0.014)\end{array}$ \\
\hline Ratio of current account to GDP ${ }^{d}$ & $\begin{array}{l}-0.045 * * \\
(0.019)\end{array}$ & $\begin{array}{l}-0.053 * * * \\
(0.019)\end{array}$ & $\begin{array}{l}-0.044 * * \\
(0.021)\end{array}$ & $\begin{array}{l}-0.056 * * * \\
(0.021)\end{array}$ \\
\hline Ratio of total public debt to GDP ${ }^{d}$ & $\begin{array}{l}0.544 * * \\
(0.220)\end{array}$ & $\begin{array}{l}0.333 \\
(0.415)\end{array}$ & $\begin{array}{l}0.578^{* *} \\
(0.234)\end{array}$ & $\begin{array}{c}0.324 \\
(0.464)\end{array}$ \\
\hline Constant & $\begin{array}{l}-1.712 * * * \\
(0.168)\end{array}$ & $\begin{array}{l}-1.834 * * * \\
(0.495)\end{array}$ & $\begin{array}{l}-2.276^{* * *} \\
(0.629)\end{array}$ & $\begin{array}{l}-1.724 * * * \\
(0.575)\end{array}$ \\
\hline No. of observations & 511 & 394 & 511 & 394 \\
\hline Pseudo- $R^{2}$ & 0.12 & 0.16 & 0.14 & 0.19 \\
\hline \multicolumn{5}{|l|}{ Crisis is currency crisis $C C 1^{\mathrm{b}}$} \\
\hline Ratio of reserves to short-term debt ${ }^{\mathrm{d}}$ & $\begin{array}{l}-0.162 * * \\
(0.065)\end{array}$ & $\begin{array}{l}-0.261 * * \\
(0.104)\end{array}$ & $\begin{array}{l}-0.130 * * \\
(0.064)\end{array}$ & $\begin{array}{c}-0.201 * \\
(0.108)\end{array}$ \\
\hline $\begin{array}{l}\text { Real exchange rate deviation from } \\
\text { Hodrick-Prescott trend }\end{array}$ & $\begin{array}{l}-1.441 * * * \\
(0.463)\end{array}$ & $\begin{array}{l}-1.332 * * * \\
(0.496)\end{array}$ & $\begin{array}{l}-1.598 * * * \\
(0.504)\end{array}$ & $\begin{array}{l}-1.547 * * * \\
(0.528)\end{array}$ \\
\hline Consumer price inflation $^{\mathrm{d}}$ & $\begin{array}{l}0.331 * * \\
(0.134)\end{array}$ & $\begin{array}{l}0.134 \\
(0.210)\end{array}$ & $\begin{array}{l}0.392 * * * \\
(0.141)\end{array}$ & $\begin{array}{c}0.161 \\
(0.231)\end{array}$ \\
\hline Constant & $\begin{array}{l}-1.148^{* * * *} \\
(0.111)\end{array}$ & $\begin{array}{c}-0.571 * \\
(0.324)\end{array}$ & $\begin{array}{l}-2.109 * * * \\
(0.404)\end{array}$ & $\begin{array}{c}-1.019 * \\
(0.585)\end{array}$ \\
\hline No. of observations & 560 & 483 & 560 & 483 \\
\hline Pseudo- $R^{2}$ & 0.07 & 0.12 & 0.13 & 0.18 \\
\hline
\end{tabular}

Source: Author's regressions.

a. Numbers in parentheses are robust standard errors. Asterisks indicate statistical significance at the ***1 percent, **5 percent, and *10 percent level.

b. Sudden stops and currency crises are defined in appendix table A-2.

c. Average of one-year and two-year lags.

d. One-year lag.

countries over 1980-2000. The preferred specifications are reported in the top panel of table 5 for sudden stops (defined as SS1) and in the bottom panel for currency crises (CC1). The explanatory variables have been selected using a general-to-specific approach, starting from a set of eighteen potential regressors, which are listed in table A-4 in appendix A. All explanatory variables are lagged at least one year and are thus predeter- 
mined with respect to the crisis. The results are robust to the inclusion of time and country fixed effects.

I find that the main explanatory variable is the real exchange rate (or, more precisely, its deviation from a trend), which appears with the expected sign in both sets of probit regressions. Consistent with the univariate evidence presented earlier, the ratio of reserves to short-term debt is significant for currency crises but not for sudden stops. The GDP growth rate, the ratio of foreign liabilities to money (a measure of dollarization in the banking sector), the current account, and total public debt are also significant in the regressions for sudden stops. Finally, the probit estimation for currency crises finds a role for inflation.

Figure 11 tracks the estimated probability of crisis over time in my sample of emerging market countries (the averages are GDP-weighted and based on the regressions without fixed effects). The probability of crisis is significantly lower in Asia than in the other emerging market countries, especially at the end of the 1990s because of the weak real exchange rates, large current account surpluses, and strong economic growth that prevailed in that region. To illustrate, the probability of a sudden stop is estimated at 2.7 percent in China in 2000, and that of a currency crisis is less than 0.2 percent.

In the second step, I compute the optimal level of reserves $R_{i}^{*}$ for each country in 2000. Parameter $v_{i}$, which captures the country's intrinsic vulnerability to a crisis, is calibrated using the probit regression for sudden stops reported in table 5. Capital flight, the output cost of the crisis, and the values for the opportunity cost of reserves and for the risk aversion parameter remain the same as in the benchmark calibration (table 4).

The results of this exercise are reported in table 6. At $\$ 234$ billion, the total predicted level of reserves for all countries in the sample is significantly below the actual level observed in 2000 (just over $\$ 650$ billion). However, the discrepancy comes mainly from the Asian countries, where the predicted level of reserves is extremely low. The estimated optimal level of reserves is zero in several important Asian countries (China, Korea, and Malaysia), because the probability of a sudden stop was below the 5 percent threshold (see figure 10). By contrast, the model works well for Latin America, where the observed level of reserves is actually slightly below the model prediction.

The last two columns of table 6 give the "implied" values for the risk aversion parameter $\sigma$ and the expected output loss in a crisis $\Delta Y$, that is, 
Figure 11. Probabilities of Currency Crises and Sudden Stops, 1980-2000

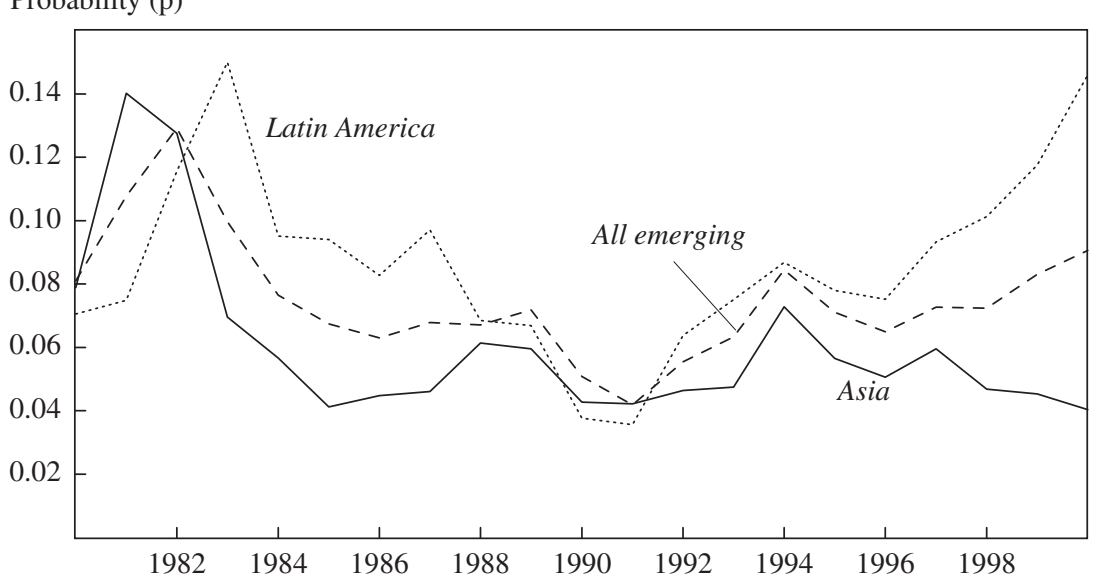

Currency crisis (CC1)

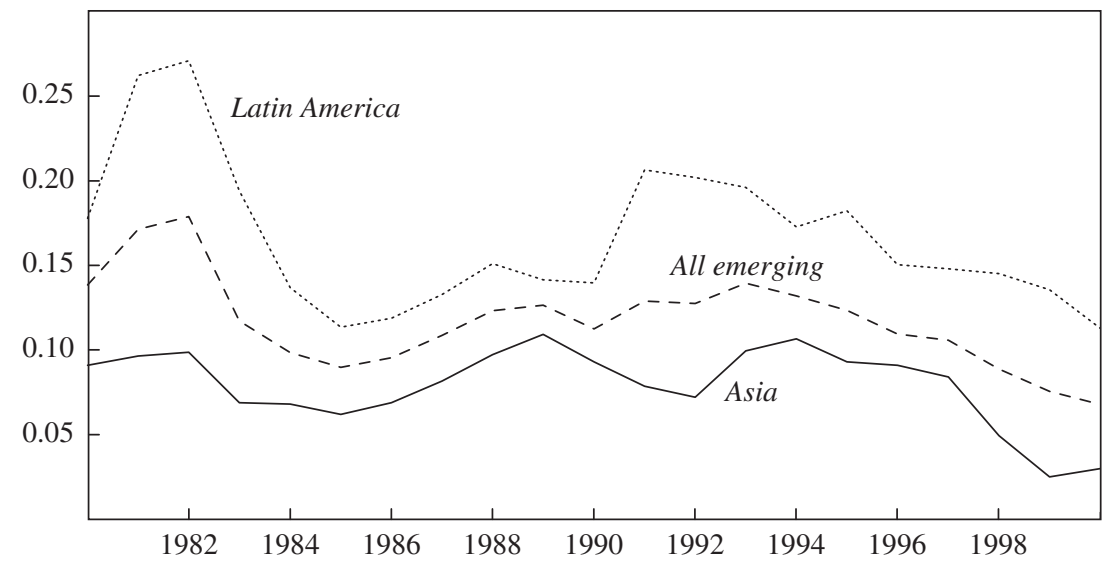

Sources: Author's calculations based on model described in text.

a. Results are GDP-weighted country averages. Excludes Russia and Ukraine. 
Table 6. Actual and Model-Predicted Levels of Reserves

\begin{tabular}{lcccc}
\hline & $\begin{array}{c}\text { Actual, 2000 } \\
\text { (billions of } \\
\text { Country group }\end{array}$ & $\begin{array}{c}\text { Penchmark }^{\mathrm{a}} \\
\text { (billions of } \\
\text { dollars) }\end{array}$ & $\begin{array}{c}\text { Implied risk } \\
\text { aversion }(\sigma)\end{array}$ & $\begin{array}{c}\text { Implied output cost } \\
\text { of a crisis }(\Delta Y \text {, } \\
\text { percent of GDP) }\end{array}$ \\
\hline All emerging market & 651 & 234 & 5.2 & 20.8 \\
$\quad$ countries & 406 & 24 & 11.7 & 30.6 \\
Asia & 145 & 153 & 1.9 & 9.6 \\
Latin America & & & & \\
\hline
\end{tabular}

Source: Author's calculations.

a. Level that minimizes the loss function in equation 10, calibrated using the probit estimation for sudden stops (SS1) reported in table 5. Excludes Russia and Ukraine.

the values that one must assign to these parameters for the model to explain the observed level of reserves. In Latin America the implied values are very close to those in the benchmark calibration (reflecting the fact that the model fits the observations well in that region). By contrast, in Asia the implied values are implausibly high-almost 12 for risk aversion and more than 30 percent of GDP for the output cost of a crisis.

The results in table 6 assume that reserves have no benefits in terms of crisis prevention. As mentioned before, the optimal level of reserves may be significantly higher if reserves have preventive benefits. Might this explain the reserves buildup in Asia? I look into this question by estimating the benefits of the reserves accumulation between 2000 and 2005 in terms of crisis prevention. For simplicity, I assume that the welfare cost of a crisis is equal to the output cost. Then increasing the level of reserves from $R$ to $R^{\prime}$ is optimal if

$$
\left[\pi\left(R^{\prime}\right)-\pi(R)\right] \Delta Y \geq \delta\left(R^{\prime}-R\right)
$$

that is, if the decrease in the expected output cost of a crisis exceeds the opportunity cost of increasing reserves. To calibrate this condition, I compute for each country in my sample the decrease in the crisis probability induced by the reserves accumulation observed between 2000 and 2005, $\Delta \pi=\pi_{i 2000}-\pi_{i 2005}$. The probabilities are estimated using the probit regression for currency crises reported in the bottom panel of table 5 . The benefits and costs of the observed reserve accumulation are computed under the assumption that a crisis costs 10 percent of potential output and that the opportunity cost of reserves is 3 percent. 
Table 7. Benefit and Cost of Reserves Accumulation, 2000-05

\begin{tabular}{lccc}
\hline Item & $\begin{array}{c}\text { All } \\
\text { emerging }^{\text {markets }}\end{array}$ & Asia & $\begin{array}{c}\text { Latin } \\
\text { America }\end{array}$ \\
\hline Change in ratio of reserves to GDP (percentage points) $^{\text {Reduction in crisis probability (percentage points) }}$ & 8.7 & 13.8 & 2.8 \\
Benefit of reserves accumulation (percent of 2000 GDP) $^{\mathrm{c}}$ & 2.2 & 1.7 & 2.6 \\
Cost of reserves accumulation (percent of 2000 GDP) $^{\mathrm{d}}$ & 0.22 & 0.17 & 0.26 \\
Implied expected output cost of crisis (percent of GDP) $^{\mathrm{e}}$ & 28.5 & 1.04 & 0.14 \\
\hline
\end{tabular}

\footnotetext{
Source: Author's calculations using IFS and WDI data.

a. The sample is composed of the emerging market countries listed in appendix table A-1 minus Morocco, Russia, and Ukraine. All results are country averages weighted by 2000 GDP.

b. Estimated from the probit regression for currency crises (CC1) reported in table 5.

c. Equals the reduction in crisis probability times the output cost of a crisis (10 percent of 2000 GDP).

d. Equals the increase in reserves times the opportunity cost of reserves (3 percent).

e. Output cost that equalizes the benefit of reserves accumulation and the cost of reserves accumulation.
}

Table 7 reports the results of this exercise for emerging market countries as a whole as well as for Asia and Latin America separately (country averages weighted by GDP). It appears that, on average, the cost of reserves accumulation exceeded the benefits in terms of crisis prevention by a factor of about 3 . But again the average masks an important difference between Asia, where the cost was more than five times larger than the benefit, and Latin America, where the benefit of reserves accumulation in terms of crisis prevention actually exceeded the cost.

The reason for this difference is that the probability of a currency crisis was much lower in Asia than in Latin America in 2000 (see figure 11), implying that the marginal returns to reserves accumulation in terms of crisis prevention were much higher in Latin America than in Asia. To illustrate, in 2000 Mexico could have reduced its estimated crisis probability from 9.6 percent to 5.6 percent by doubling its reserves. By contrast, in China the estimated probability of crisis was 0.2 percent in 2000 and so could not have been reduced much further. It is nevertheless in emerging market Asia that most of the recent reserves accumulation has taken place.

Finally, the last line of table 7 reports the "implied" output loss for each country, that is, the minimum output cost that one must assume for the observed accumulation of reserves between 2000 and 2005 to be worth the cost. To rationalize the reserves buildup in Asian emerging market countries, one needs to assume that the output cost of a crisis amounts to more than 60 percent of GDP; the implied output cost is less than one-tenth that size in Latin America.

The conclusion is that the model cannot reasonably account for the increase in reserves in Asian emerging market countries as self-insurance 
against capital account crises. It can only do so by assuming that a capital account crisis costs more than 60 percent of one year's output, which is out of line with the historical experience. ${ }^{33}$

\section{Discussion}

To summarize, one justification for emerging market countries holding liquid international reserves is as a means of dealing with capital flow volatility and the risk of capital account crisis, but the evidence suggests that most countries (especially in Asia) hold more international reserves than can be justified by this objective. This raises several questions. Why have Asian emerging market countries accumulated such large reserves? How should those reserves be managed? And looking forward, what are the implications of this buildup in emerging market countries' foreign assets for the international financial system?

\section{Trade Surpluses and Sovereign Wealth}

Having rejected the view that the recent reserves accumulation can be justified on a precautionary basis, one has to consider as the main alternative explanation that these reserves are the unintended consequence of large current account surpluses. ${ }^{34}$ The "mercantilist" variant of this view holds that the central banks of these countries are accumulating reserves in order to resist the appreciation of the domestic currency ${ }^{35}$ For this effort not to be defeated by domestic inflation, it must be augmented by

33. However, this may not be an implausible order of magnitude for the cost of a severe banking crisis.

34. Another alternative is the view that the high-growth developing countries are exporting their savings abroad because of a shortage of domestic assets for their residents to invest in (Caballero, 2006). These capital outflows must take the form of reserves accumulation if residents' holdings of foreign assets are restricted by capital controls.

35. The nonmercantilist variant would hold that these countries' competitiveness results from natural factors (for example, that wages are kept low in the export sector by a reserve army of labor migrating from the traditional sectors) rather than policy-induced distortions. Mercantilism is at the core of the "Bretton Woods II" view (Dooley, Folkerts-Landau, and Garber, 2004) of the international financial system. Although many commentators find this view quite plausible, it is not obvious how to confirm or reject it empirically. For example, Aizenman and Lee (2005) find that variables associated with the mercantilist motive (lagged export growth and deviations from predicted purchasing power parity) explain very little of the cross-country difference in reserves accumulation. 
policies that repress domestic demand-for example, capital controls or domestic financial repression.

Table 8 shows, for the same sample of emerging market countries, the cross-country correlations between the increase in the reserves-GDP ratio between 2000 and 2005 and some key macroeconomic variables. It appears that reserves accumulation is strongly correlated with the current account surplus and not correlated at all with the change in gross external liabilities. This suggests that, to a first approximation, the accumulation of reserves reflects net export flows rather than balance sheet operations.

The change in the reserves-GDP ratio is also positively correlated with capital account restrictions and with the real GDP growth rate. ${ }^{36}$ The correlation with capital account restrictions is the opposite of what one would expect based on the precautionary view of reserves accumulation, which predicts that countries with a more open capital account should hold more precautionary reserves because they are more vulnerable to the volatility of capital flows. The positive correlation with the growth rate is also puzzling if one thinks that high-growth developing countries should be importing foreign capital to finance their development, but it is consistent with the mercantilist view, if one thinks that undervaluation of the domestic currency stimulates growth. ${ }^{37}$

One could develop a cost-benefit welfare analysis of a mercantilist development strategy in the same way as I have done for the precautionary view, but the trade-offs involved would be very different. On the cost side, one would have to count the various distortions that are necessary to repress domestic demand, as well as the valuation loss on the foreign assets accumulated by the authorities when the inevitable real appreciation eventually takes place. The benefit side would include the gains in terms of productivity and growth from stimulating the export sector.

It is important to understand that what such a cost-benefit analysis would endogenize is not the level of reserves $R$, but rather the level of total publicly held foreign assets, which was denoted by $W_{0}$ and taken as exogenous in my model of reserves. Endogenizing $W_{0}$ would not affect my con-

36. The correlation is less significant for capital account restrictions than for the current account balance or the growth rate, and it seems less robust-it is no longer significant if one uses Edwards' (2001) measure of capital mobility rather than Chinn and Ito's (2005).

37. As Gourinchas and Jeanne (2006) have shown, high-growth developing countries tend to export capital, a puzzle that is explained in part by reserves accumulation. See also Prasad, Rajan, and Subramanian in this volume. 


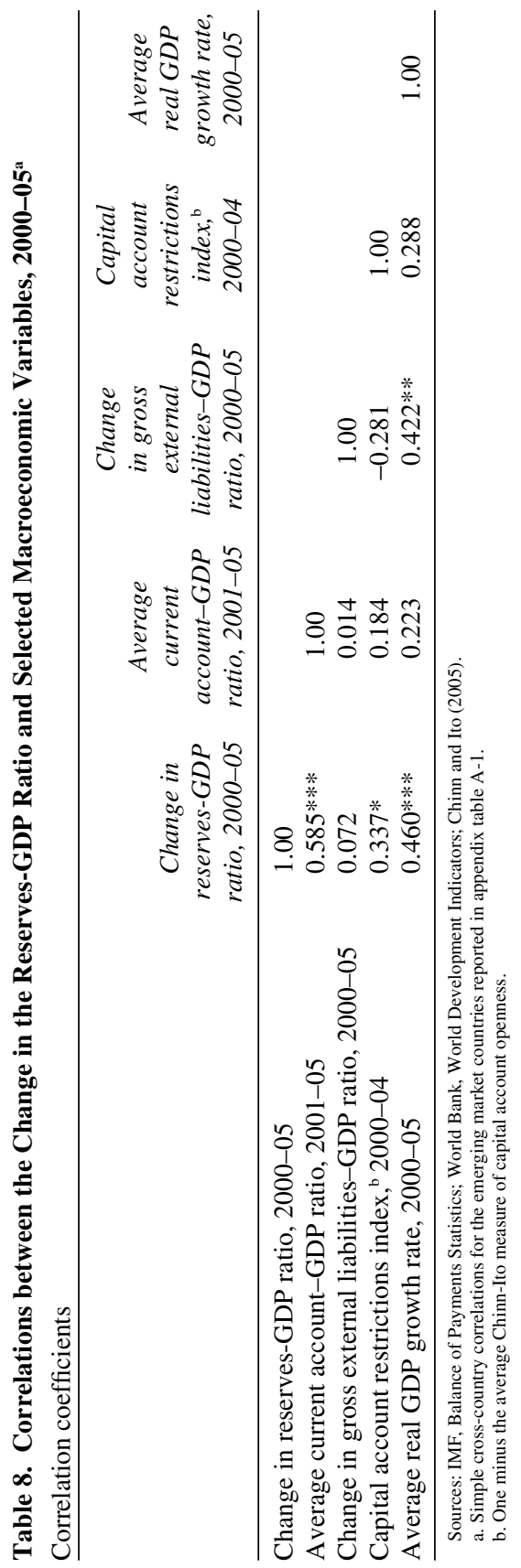


clusion that most emerging market countries in Asia have excess reserves from the point of view of crisis insurance. Those excess reserves are costly, first in terms of forgone returns and portfolio diversification, and second because they generate difficulties for domestic monetary control that can be mitigated only by introducing or maintaining costly distortions in the domestic banking and financial system.

The governments of emerging market countries have started to mitigate these costs by transferring a fraction of foreign exchange reserves from the central bank to "sovereign wealth funds." ${ }^{38}$ These funds are mandated to invest in a more diversified portfolio and at a longer horizon than central banks-not unlike the natural resource-based stabilization funds set up by a number of commodity exporters. For example, since July 2005 a fraction of Korea's reserves have been managed by an independent entity, the Korean Investment Corporation, with the aim of seeking higher yields. China recently established the State Foreign Exchange Investment Corporation to manage reserves outside of the central bank.

According to some estimates, the holdings of sovereign wealth funds already amount to more than $\$ 2$ trillion, mostly consisting of funds derived from oil and gas exports, but their size could increase to $\$ 12$ trillion by 2015, surpassing official reserves within five years. ${ }^{39}$ If those estimates are correct, sovereign wealth funds are set to become a major force in the international financial system.

\section{Portfolio Diversification}

Although, as just described, central banks in emerging market countries have recently been diversifying their allocation of reserves, this trend has been slow, and central banks continue to allocate their portfolios in a significantly different manner than private investors do. ${ }^{40}$ To illustrate, figure 12 compares the allocation of U.S. assets held by the foreign official sector with that of foreign private investors. The foreign official sector invests much more in U.S. government debt and much less in equity or

38. See Rozanov (2005) and Johnson-Calari and Rietveld (2007). Another approach would be to give the private sector more direct control over the allocation of the country's foreign assets, as in Prasad and Rajan's (2005) proposal to set up closed-end mutual funds that purchase reserves from the central bank and invest the proceeds abroad.

39. See Jen (2007).

40. On recent trends in reserves diversification see Knight (2006), Woolridge (2006), and Truman and Wong (2006). 
Figure 12. Composition of Foreign Official and Nonofficial Holdings of U.S. Assets, 2005

Percent of total

\section{Official sector}

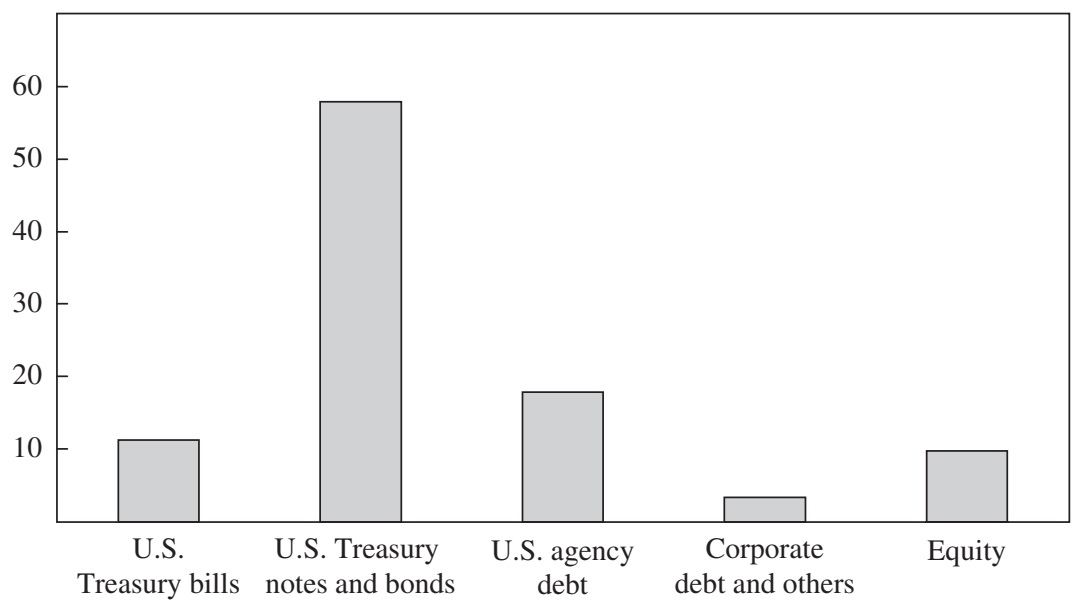

Nonofficial sector

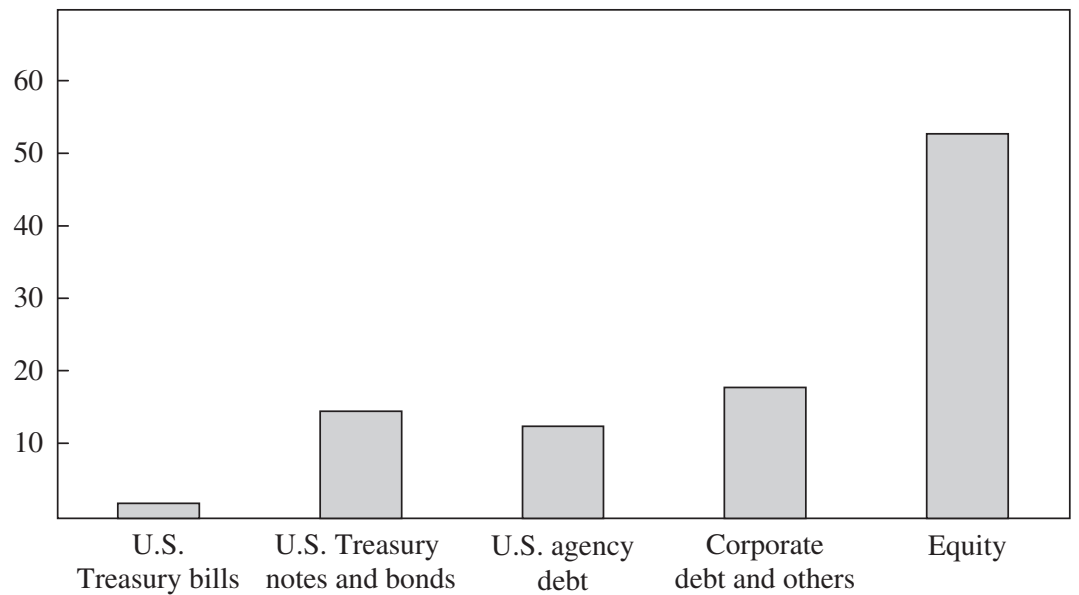

Sources: U.S. Treasury, Treasury International Capital database. 
Table 9. Impact of Emerging Market Reserves Diversification on Financial Market Capitalization ${ }^{\mathrm{a}}$

\begin{tabular}{|c|c|c|c|c|}
\hline Item & $\begin{array}{l}\text { United } \\
\text { States }\end{array}$ & $\begin{array}{l}\text { Euro } \\
\text { area }\end{array}$ & Japan & $\begin{array}{c}\text { United } \\
\text { Kingdom }\end{array}$ \\
\hline \multicolumn{5}{|l|}{ Equity } \\
\hline Current stock (billions of dollars) & 16,800 & 6,000 & 4,200 & 3,000 \\
\hline Expected change in demand ${ }^{a}$ (percent) & $(+0.40)$ & $(+0.66)$ & $(+0.66)$ & $(+0.66)$ \\
\hline \multicolumn{5}{|l|}{ Bonds } \\
\hline Current stock (billions of dollars) & 19,800 & 8,400 & 8,700 & 1,000 \\
\hline Expected change in demand (percent) & $(-1.39)$ & $(+0.66)$ & $(+0.66)$ & $(+0.66)$ \\
\hline \multicolumn{5}{|l|}{ Of which: U.S. Treasury marketable debt } \\
\hline Current stock (billions of dollars) & 4,000 & & & \\
\hline Expected change in demand (percent) & $(-7.1)$ & & & \\
\hline
\end{tabular}

corporate debt than do private investors. Clearly there remains significant scope for diversification, a trend that should be facilitated by the transfer of emerging market countries' reserves to sovereign wealth funds.

Some have expressed concern that the diversification of emerging market countries' reserves could lead to disruptions in exchange rates and the relative prices of financial assets. To shed light on this question, consider, for the sake of argument, the following experiment. The total stock of foreign exchange reserves in my sample of emerging market countries amounted to approximately $\$ 2$ trillion dollars in 2005. Assume that $\$ 1.2$ trillion of this (60 percent of the total) was invested in dollar assets, of which $\$ 900$ billion was invested in the asset classes represented in figure $12 .{ }^{41}$ Assume further that the emerging market countries in my sample reinvest half of the assets currently invested in the official sector's portfolio shown in figure 12 ( $\$ 450$ billion) in the global financial portfolio. What would be the impact on the net supply of financial assets for the rest of the global investor community?

Table 9 details the current structure of the global portfolio of financial assets. The table was constructed by aggregating World Bank cross-

41. Figure 12, which is based on data from the Treasury International Capital (TIC) database, does not report foreign official investment in onshore or offshore dollar deposits and repurchase agreements, which amount to about one-fourth of the total (Knight, 2006, table 2). 
country data on stock and bond market capitalizations in the industrial countries. The table also shows, for each asset class, the net demand from emerging market countries that would be induced by the assumed portfolio reallocation, as a percentage of the outstanding stock. For example, the demand for U.S. bonds would decrease by 1.39 percent of the outstanding stock, while the demand for Japanese equity would increase by 0.66 percent of the outstanding stock.

As one would expect, the selling pressure would play against the dollar, especially fixed-income dollar assets (net demand for U.S. equity would actually increase with the diversification). Net demand for U.S. assets would decrease by 0.5 percent of the outstanding stock, while that for nonU.S. assets would increase by 0.66 percent.

Overall, this back-of-the-envelope calculation shows that the changes in net demand would amount to relatively small fractions of the outstanding stocks. This suggests that moderate price and exchange rate changes would suffice to restore equilibrium. This conclusion, however, comes with several caveats. First, the net supply exceeds 7 percent of the outstanding stock if one restricts one's attention to marketable U.S. Treasury debt. This results from the fact that the foreign official sector holds a significant fraction—about one-third—of outstanding U.S. government debt. ${ }^{42}$ The impact on the interest rate that the U.S. government pays on its debt might thus be nonnegligible, depending on its substitutability with other forms of dollar debt in the portfolios of global investors. ${ }^{43}$

Second, the short-run price effects of portfolio diversification will depend on the pace of the diversification and on the reaction of private investors. Whereas the literature on sterilized foreign exchange intervention suggests that such interventions have moderate and transitory effects on exchange rates, the microstructure literature shows that their impact might be large (at least in the short run), especially in markets that lack depth and in which information is fragmented. Furthermore, private speculation may not be stabilizing - private investors might want to get out in front of any government moves rather than offset them as they occur. So, although it is

42. See Parisi-Capone and Setser (2006).

43. Warnock and Warnock (2006) find that foreign demand for Treasury securities has a significant impact on Treasury yields. A study by the European Central Bank (2006) finds that the interventions conducted by Asian central banks cannot be shown to be responsible for the low yields in the United States, although they have certainly played a role. 
unlikely that large price and exchange rate adjustments must result, in the long run, from increased diversification of emerging market countries' foreign assets, there certainly is a need for the international community to assess and monitor the risks in the transition.

\section{Collective Arrangements}

The abundance of reserves held by emerging market countries reduces the need for collective insurance-such as that provided by the IMF at the global level, or by the Chiang Mai Initiative or the Latin American Reserve Fund at the regional level. Indeed, the resources of collective insurance arrangements have become relatively small compared with the reserves that emerging market countries have recently accumulated. For example, the increase in reserves in the Asian emerging market countries over 2000-05 amounts to more than four times the IMF's usable resources at the end of 2005, and more than twenty times the bilateral swap agreements under the Chiang Mai Initiative signed over 2001-05. The buildup in reserves explains in part the recent decline in IMF credit outstanding, which is likely to persist for some time. ${ }^{44}$

Looking forward, one question is whether the large accumulated stocks of sovereign wealth could be used to collectively insure risks other than capital account crises. Emerging market countries face other risks that are now largely uninsured, such as natural disasters, epidemics, terms of trade shocks, and severe output drops..$^{45}$ Although some of these risks may be uninsurable because of the potential for moral hazard, there might be scope for expanding insurance through appropriate collective intervention at the regional or the global level.

Finally, sovereign wealth can be used to induce the development of regional financial markets. An example of this is the Asian Bond Fund, created in 2003 to diversify the investment of Asian central banks' reserves away from U.S. and European securities into Asian bonds. Since 2005 the Asian Bond Fund has also invested in domestic currency bonds issued by

44. Using various models of the demand for IMF loans, Ghosh and others (2007) project that IMF credit outstanding will decline from an average of SDR 50 billion over 2000-05 to SDR 8 billion over 2006-10, in part because of the increase in the reserves-toshort-term-debt ratio in emerging market countries.

45. See Becker and others (2007). 
regional sovereign issuers, as a catalyst for private investment in Asian issues. ${ }^{46}$ Such initiatives might enable emerging market countries to develop debt instruments (with long maturities and domestic currency denomination) that are safer for their borrowers.

\section{Summary and Conclusions}

This paper has argued that reserves accumulation in Asian emerging market countries is difficult to justify-at least since 2000-in terms of self-insurance against capital flow volatility and capital account crises. The main piece of evidence behind this claim is the failure of a simple cost-benefit model of optimal reserves to account for the reserves buildup in these countries since 2000: their vulnerability to a capital account crisis was too low in that year to justify the cost of the accumulated reserves. That reserves were excessive from the point of view of crisis insurance is also suggested by recent moves to reallocate reserves from central banks to sovereign wealth funds investing in less liquid, higher-yielding assets.

Even if the rate of accumulation of reserves were to abate-and notwithstanding the good reasons that it should-the public sectors of a number of emerging market countries, especially in Asia, will have to manage stocks of foreign financial assets of unprecedented size for some time to come. This generates both policy challenges and opportunities for the international community. One challenge is to ensure that the diversification of those assets is conducted in an orderly manner, to avoid large or abrupt changes in the relative prices of financial assets or in exchange rates. An opportunity lies in the fact that this increase in sovereign wealth could provide the basis for cross-country insurance arrangements against risks other than capital account crises, or could catalyze regional financial development.

46. Eichengreen (2006) recommends that the Latin American Reserve Fund follow a similar course of action. 
APPENDIX A

\section{Data and Definitions}

Table A-1. Countries in the Sample

\begin{tabular}{llll}
\hline \multicolumn{1}{c}{ Emerging $_{\text {market }}$ countries $^{\mathrm{a}}$} & \multicolumn{2}{c}{ Industrial $_{\text {countries }}{ }^{\mathrm{b}}$} \\
\hline Argentina & Mexico & Australia & Norway \\
Brazil & Morocco & Austria & Portugal \\
Bulgaria & Nigeria & Belgium & Spain \\
Chile & Pakistan & Canada & Sweden \\
China & Panama & Denmark & Switzerland \\
Colombia & Peru & Finland & United Kingdom \\
Côte d'Ivoire & Philippines & France & United States \\
Dominican Republic & Poland & Germany & \\
Ecuador & Russia & Greece & \\
Egypt & South Africa & Iceland & \\
El Salvador & Thailand & Ireland & \\
Hungary & Tunisia & Italy & \\
India & Turkey & Japan & \\
Indonesia & Ukraine & Luxembourg & \\
Korea & Uruguay & Netherlands & \\
Malaysia & Venezuela & New Zealand & \\
\hline
\end{tabular}

a. All countries in the JP Morgan Emerging Market Bond Index Global (EMBIG) as of August 31, 2005, excluding Serbia and Montenegro and Lebanon because of data availability, and adding India and Korea.

b. Countries that were members of the Organization for Economic Cooperation and Development in 1990 and are not in the list of emerging market countries. 
Table A-2. Crisis Definitions

\begin{tabular}{|c|c|c|}
\hline Crisis type & Source & Definition \\
\hline \multicolumn{3}{|l|}{ Currency crises } \\
\hline $\mathrm{CC} 1$ & $\begin{array}{l}\text { Frankel and Rose } \\
\text { (1996) }\end{array}$ & $\begin{array}{l}\text { A nominal depreciation of the currency of at } \\
\text { least } 25 \text { percent relative to the previous year } \\
\text { that is also at least a } 10 \text { percent acceleration, } \\
\text { year over year, in the rate of depreciation. }\end{array}$ \\
\hline $\mathrm{CC} 2$ & $\begin{array}{l}\text { Frankel and Wei } \\
\quad(2005)\end{array}$ & $\begin{array}{l}\text { A year is identified as a crisis year if, in at least } \\
\text { one month, the sum of the monthly percentage } \\
\text { nominal depreciation and the percentage loss } \\
\text { in foreign reserves exceeds } 15 \text {. The sum of } \\
\text { the percentage nominal depreciation and the } \\
\text { percentage loss in reserves must also be } \\
10 \text { percentage points greater than in the } \\
\text { previous month. In cases where successive } \\
\text { years may satisfy the crisis criterion, only } \\
\text { the first year of crisis is counted within any } \\
\text { three-year window. }\end{array}$ \\
\hline $\mathrm{CC} 3$ & $\begin{array}{l}\text { Frankel and Wei } \\
\text { (2005) }\end{array}$ & $\begin{array}{l}\text { Same as CC2 except that the sum of the } \\
\text { percentage nominal depreciation and the } \\
\text { percentage loss of foreign reserves must } \\
\text { exceed } 25 .\end{array}$ \\
\hline $\mathrm{CC} 4$ & $\begin{array}{l}\text { Frankel and Wei } \\
\text { (2005) }\end{array}$ & $\begin{array}{l}\text { Same as CC } 2 \text { except that the sum of the } \\
\text { percentage nominal depreciation and the } \\
\text { percentage loss of foreign reserves must } \\
\text { exceed } 35 \text {. }\end{array}$ \\
\hline
\end{tabular}

Sudden stops

$\begin{array}{ll}\text { SS1 } & \begin{array}{c}\text { Jeanne and } \\ \text { Rancière (2006) }\end{array} \\ \text { SS2 } & \text { Frankel and } \\ & \text { Cavallo (2004), } \\ & \text { "sudden stop 1" }\end{array}$

SS3

SS4
Frankel and

Cavallo (2004), "sudden stop 2"

Frankel and

Cavallo (2004), "sudden stop 3"
The ratio of net capital inflows ${ }^{\text {a }}$ to GDP falls by more than 5 percent relative to the previous year.

A reduction in the financial account from a surplus position with respect to the previous year that is 2 standard deviations above the mean standard deviation (the average of standard deviations of the financial account over the entire sample). A fall in GDP per capita and in the current account deficit must accompany the financial account reduction, during either the same year or the next year.

Same as SS2 except that the mean standard deviation of the financial account is that over the corresponding decade only.

Same as SS2 except that the mean standard deviation is computed for the year-to-year change in the financial account rather than the level.

a. Net capital inflows are measured as the sum of the capital and financial account plus net errors and omissions minus reserve assets and use of Fund credit (from IMF, Balance of Payments Statistics). 


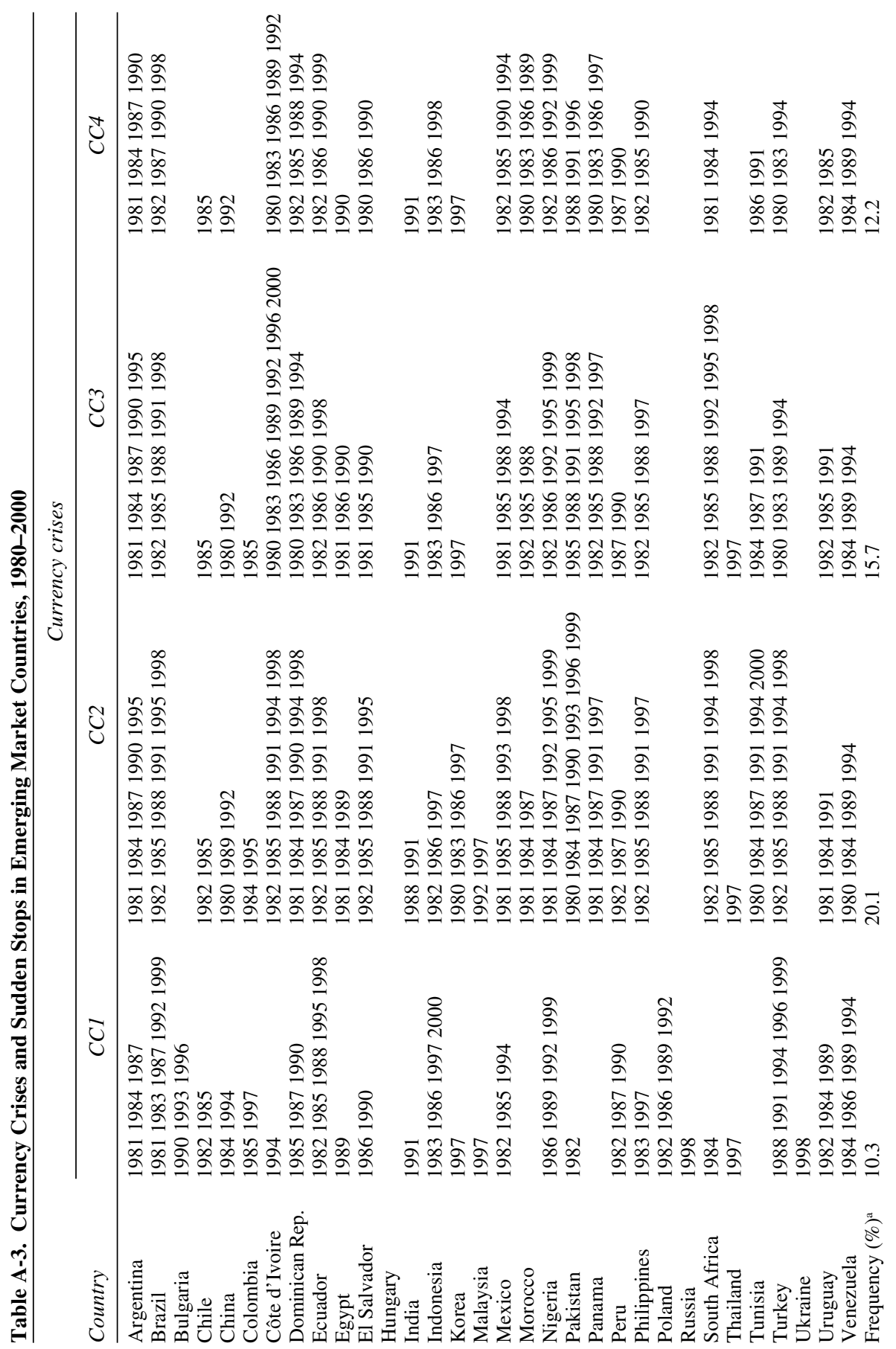




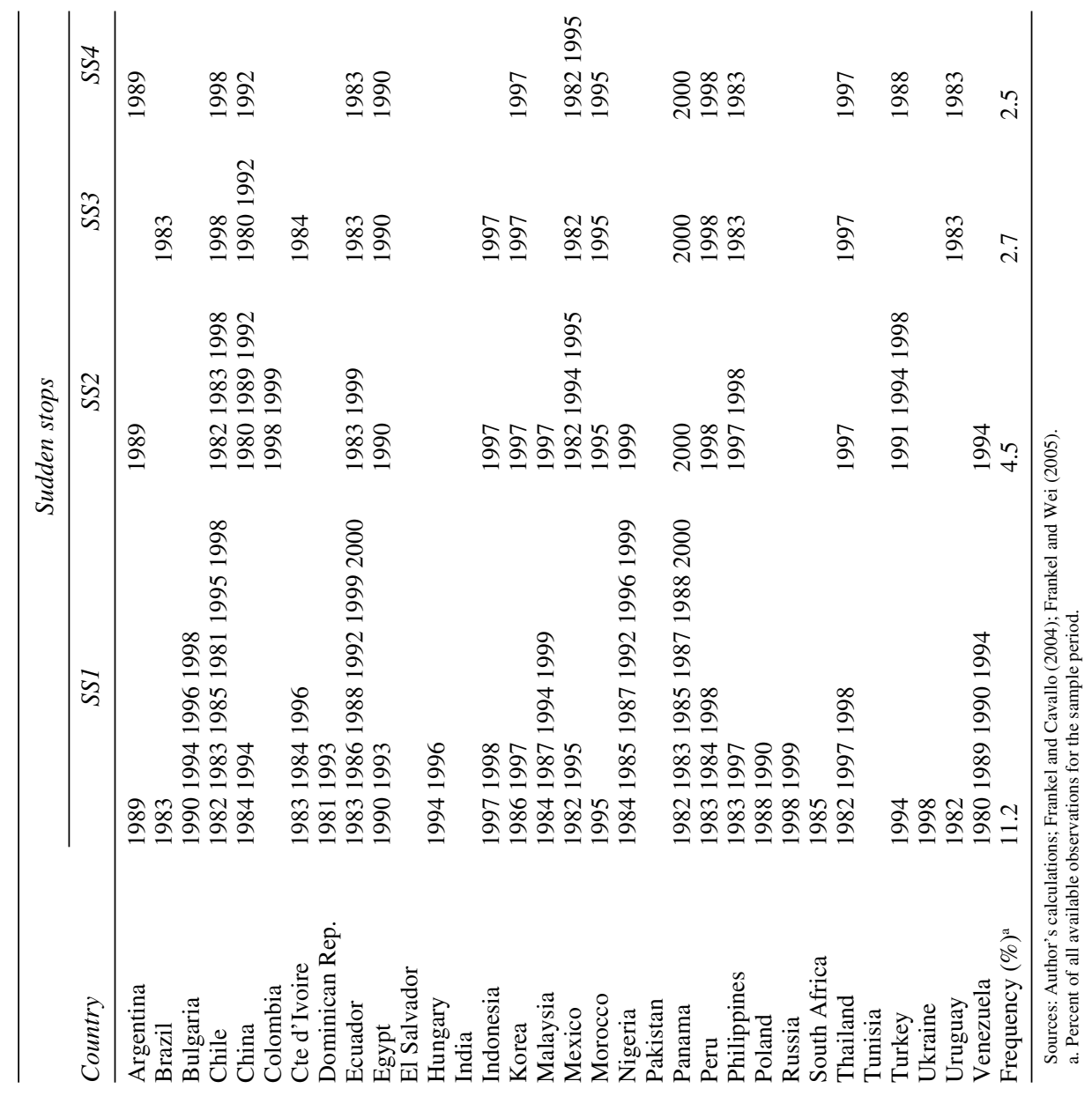


Table A-4. Variables Considered in the Probit Analysis

\begin{tabular}{ll}
\hline Variable $^{\mathrm{a}}$ & Source \\
\hline Annual growth in GDP & WDI \\
Current account balance & IFS \\
Reserves & IFS \\
M2 & IFS
\end{tabular}

Debt

Ratio of lagged real public debt to real GDP

Ratio of lagged short-term debt to real GDP

GDF, WDI

GDF, WDI

Exchange rate

Second lag of exchange rate regime dummies

Lagged real effective exchange rate deviation from Hodrick-Prescott trend

Reinhart and Rogoff (2004)

IFS

Trade

Ratio of lagged sum of exports and imports to GDP

WDI

Lagged growth in terms of trade (percent)

IFS

Index of current account openness

Quinn (2000)

\section{U.S. interest rates}

Interest rate on Treasury bills (percent a year)

Change in the interest rate on Treasury bills (basis points)

IFS

IFS

Business cycle indicators

Average of first and second lags of real GDP growth

WDI

Financial account openness

Ratio of lagged absolute gross inflows to GDP

Ratio of lagged sum of absolute gross inflows and absolute gross outflows to GDP

IFS

IFS

Stocks of foreign assets and foreign liabilities

Ratio of lagged net foreign assets to GDP

Ratio of lagged stock of foreign liabilities to GDP

Lane and Milesi-Ferretti (2006)

Lane and Milesi-Ferretti (2006)

Ratio of stock of debt liabilities to stock of

Lane and Milesi-Ferretti (2006) total liabilities

Ratio of lagged stock of FDI to stock of total liabilities

Lane and Milesi-Ferretti (2006)

Other

Ratio of foreign liabilities to money in the financial sector

IFS

Consumer price inflation (percent a year)

IFS

a. Lags are one-year lags except where stated otherwise.

b. Definitions: GDF, Global Development Finance (World Bank); IFS, International Financial Statistics (IMF); WDI, World Development Indicators (World Bank). 
APPENDIX B

\section{Solving for the Optimal Level of Reserves}

RESERVES MANAGEMENT IN A CRISIS. How does the country in the model use its reserves in period 1 ? If there is no crisis, the consumer achieves the desired level of consumption $C^{*}$ and saves any residual wealth (which could be positive or negative) as net reserves. But if there is a crisis, the consumer may be unable to consume $C^{*}$. Then, using equation 4 in the text, $Y_{1}=Y-\Delta Y$, and $L^{\prime}=0$, period-1 consumption is given by

$$
C_{1}=Y-\Delta Y-L+R-R^{\prime}
$$

The question is whether the consumer can achieve the desired level of consumption $C_{1}=C^{*}$ by running down reserves $\left(R^{\prime}=0\right)$. This is the case if reserves $R$ exceed the following threshold:

$$
\bar{R}=L+\Delta Y+\left(C^{*}-Y\right)
$$

$\bar{R}$ is the "full insurance" level of reserves, that is, the amount that allows the consumer to maintain consumption as if there were no crisis. It is also the maximum amount of reserves that the consumer is ready to spend in a crisis. The "full insurance" level of reserves is equal to the sum of the capital outflow and output fall in a crisis, plus the period- 1 trade deficit. The last term is equal to zero because of the assumption that $C^{*}=Y$.

THE LOSS FUNCTION (EQUATION 7). Period-0 welfare is given by

$$
U_{0}=(1-\pi) U_{1}^{n}+\pi U_{1}^{c}=U_{1}^{n}-\pi f(R),
$$

where $U_{1}^{n}$ is the welfare level conditional on no crisis, and $U_{1}^{c}$ is that conditional on a crisis, and $f(R)=U_{1}^{n}-U_{1}^{c}$ is the welfare cost of a crisis. Using equations 3 and 4 to substitute out $I$ and $R^{\prime}-L^{\prime}$ from equation 5 , we can write period-1 welfare as

$$
\begin{aligned}
U_{1} & =u\left(C_{1}\right)+\frac{W_{2}}{1+r} \\
& =u\left(C_{1}\right)+Y_{1}+(1+r)(1+\delta) W_{0}-L-C_{1}-\delta R .
\end{aligned}
$$


(I set $Y_{2}=0$ to reduce the amount of algebra.) If there is no crisis, $C_{1}=Y_{1}=$ $C^{*}=Y$, so that welfare is given by

$$
\begin{aligned}
U_{1}^{n} & =u\left(C^{*}\right)+(1+r)(1+\delta) W_{0}-L-\delta R \\
& =\bar{U}-\delta R
\end{aligned}
$$

where $\bar{U}$ is the consumer's ex ante welfare if there is no crisis risk and $W_{0}$ is invested in the illiquid asset. By contrast, if there is a crisis, $Y_{1}=Y-\Delta Y$ and $R^{\prime}=0$ (assuming $\left.R \leq \bar{R}\right)$, so that $C_{1}=Y-\Delta Y-L+R=C^{*}-(\bar{R}-R)$, implying a welfare level of

$$
U_{1}^{c}=u\left[C^{*}-(\bar{R}-R)\right]+(1+r)(1+\delta) W_{0}-L-\Delta Y+(\bar{R}-R)-\delta R .
$$

Taking the difference, one obtains $U_{1}^{n}-U_{1}^{c}=f(R)$, with

$$
f(R)=\underbrace{\Delta Y}_{\text {output cost }}+\underbrace{u\left(C^{*}\right)-u\left[C^{*}-(\bar{R}-R)\right]-(\bar{R}-R)}_{\text {consumption smoothing cost }}
$$

(if $R \leq \bar{R}$ ). The welfare cost of a crisis is the sum of two components: the output cost of the crisis and the cost of distorting the path of domestic consumption away from the unconstrained equilibrium. The second component, which is decreasing with $R$ and equal to zero if $R \geq \bar{R}$, captures the benefit of reserves in terms of crisis mitigation in my model. Finally, period-0 welfare can be written

$$
U_{0}=\bar{U}-[\delta R+\pi f(R)]
$$

\section{An Extension with Debt and Default}

Assume that reserves are financed by long-term debt $D=-I$, and assume $W_{0}=0$, so that $R=D$. There is no need to assume that debt is illiquid in the same sense as the physical investment- the debt could be traded in a liquid market. What is important for my results is that $I$ cannot be decreased (or, equivalently, $D$ cannot be increased) in a crisis. For debt this is an implication of the credit constraint to which the consumer is subject during a crisis. 
Let us assume that the consumer fails to repay long-term debt $D$ with probability $\mu$ and therefore pays a risk premium $[1 /(1-\mu)]-1$. Then the expression for final wealth (equation 5) is

$$
W_{2}=Y_{2}-\eta \frac{(1+r)^{2}(1+\delta)}{1-\mu} D+(1+r)\left(R^{\prime}-L^{\prime}\right),
$$

where $\eta$ takes the value of 1 if the consumer repays the debt and 0 if not. The expression for the expected wealth $E_{1}\left(W_{2}\right)$, and thus the expressions for $U_{1}^{n}$ and $U_{1}^{c}$, are the same as before. Hence the default probability $\mu$ has no impact on the optimal level of reserves; only $\delta$ should be counted in the opportunity cost of reserves.

However, the risk of default could be relevant if there are default costs. Assume that $Y_{2}$ is stochastic and default occurs only if the debt repayment exceeds the cost of default $\gamma Y_{2}$. Then, given $D=R$, the probability of default $\mu$ is endogenous and is solved by

$$
\mu=\operatorname{Pr}\left[\gamma Y_{2}<\frac{(1+r)^{2}(1+\delta)}{1-\mu} R\right] .
$$

This equation implicitly defines a default threshold $\bar{Y}(R)$ that is increasing with $R$. The ex ante loss becomes

$$
\text { Loss }=\delta R+\gamma \int_{0}^{\bar{\gamma}(R)} Y_{2} g\left(Y_{2}\right) d Y_{2}+\pi(R) f(R) .
$$

The opportunity cost of reserves includes a term for the deadweight cost of default, which is increasing with reserves. This term is not the same as the default risk premium, $[1 /(1-\mu)]-1$. 


\section{Comments and Discussion}

Joshua Aizenman: Since the 1980s, the world economy has witnessed an intriguing development: despite the proliferation of more flexible exchange rate regimes, ratios of international reserves to GDP have increased substantially, and practically all of that increase has taken place in developing countries, mostly in East Asia. This puzzling phenomenon has stirred a lively debate among economists and financial observers, and several interpretations have been offered. These focus on the observation that the deeper financial integration of developing countries into the global economy has increased their exposure to volatile short-term flows of capital (dubbed "hot money"), which are subject to costly and frequent sudden stops and reversals. ${ }^{1}$ In these circumstances, hoarding international reserves can be viewed as a precautionary adjustment, reflecting the desire for self-insurance against exposure to future sudden stops, currency crises, and capital flight. ${ }^{2}$

In this paper, Olivier Jeanne appraises the explanatory power of selfinsurance models of international reserves. He provides a careful formulation of a utility-based welfare analysis of optimal hoarding of international reserves, and a calibration that allows one to evaluate the degree to which recent hoarding trends are consistent with the model's predictions. The framework is based on an elegant model, providing strong predictions about optimal usable reserves in the context of self-insurance against sudden stops and currency crises. Applying the model to the data produces some intriguing results: for the typical emerging market country, the model

1. See, for example, Calvo (1998) and Edwards (2004).

2. See Flood and Marion (2002) for an overview of the literature explaining international reserves applying the buffer stock approach. See Ben Bassat and Gottlieb (1992), Aizenman and Marion (2003), Lee (2004), Aizenman and Lee (2005), Garcia and Soto (2004), Jeanne and Rancière (2006), and Rodrik (2006) for precautionary and self-insurance models of international reserves hoarding. 
can plausibly explain a reserves-GDP ratio on the order of 10 percent, close to the long-run historical average, and it can justify even higher levels if one assumes that reserves have a significant role in terms of crisis prevention. The levels of reserves recently observed in many countries, in particular in Latin America, are within the range of the model's predictions. For emerging market countries in the aggregate, however, the insurance model fails to account for the recent reserves buildup, because the risk of a capital account crisis in the Asian countries where most of the buildup has taken place seems much too small to justify such levels of self-insurance.

Jeanne's paper is an important and timely contribution to the debate about the relative costs and benefits of hoarding reserves. Yet his results raise the question of what factors might account for the sizable gaps between the model's predictions and the actual hoarding of reserves observed during recent years. After briefly summarizing his methodology and key results, I will discuss several alternative interpretations of reserves hoarding during the 2000s that go beyond the self-insurance paradigm, and I will offer several extensions that may improve the explanatory power of Jeanne's model.

THE MODEL AND ITS CALIBRATION. Jeanne's framework explains hoarding of international reserves in the context of a small open economy populated by a representative consumer and exposed to crises triggered by a loss of access to external credit, possibly associated with a fall in output. The model has three periods. The focus of the analysis is on the optimal hoarding of net reserves in period 0 , when the representative consumer anticipates the possibility of a sudden stop and a costly foreign currency crisis in period 1. The consumer's welfare is the sum of the expected utility of consumption in period 1 plus discounted expected (terminal) wealth in period 2.

Within this framework, Jeanne provides a carefully worked-out model in which international reserves affect welfare in two distinct ways. The first is through crisis prevention: an increase in reserves may reduce the probability of a crisis and thus directly reduce the expected output cost. The second is through crisis mitigation: reserves may reduce the cost of smoothing consumption during a crisis. In this model optimal international reserves are shown to be determined by minimizing a loss function, where the total loss equals the sum of the opportunity cost of reserves and the expected welfare cost of a crisis.

The model is calibrated in two steps. First, using multivariate probit regressions on data for a group of emerging market countries from 1980 to 
2000, Jeanne estimates for each country its vulnerability to a crisis in 2000. Next he computes the optimal level of reserves that minimizes the loss function. He finds that the predicted level of optimal reserves in 2000 across all countries in the sample is about $\$ 235$ billion, or about 35 percent of the actual level observed (close to $\$ 650$ billion). The discrepancy comes mainly from the Asian countries, where the predicted level of reserves is extremely low, reflecting a very low estimated probability of a sudden stop. By contrast, the model works well for Latin America, where the observed level of reserves is actually slightly below the model's prediction.

Next Jeanne estimates the benefits of the reserves accumulation between 2000 and 2005 in terms of crisis prevention, assuming that the welfare cost of a crisis is equal to the output cost. The results are striking: on average, the cost of reserves accumulation exceeds the benefits in terms of currency crisis prevention by a factor of three. This average aggregates the differences between Asia, where the cost was more than five times larger than the benefit, and Latin America, where the benefit actually exceeded the cost. These differences reflect the much lower probability of a currency crisis in Asia than in Latin America in 2000, implying that the marginal returns to reserves accumulation in terms of crisis prevention were much higher in Latin America. Applying the model, one can conclude that, to rationalize the reserves buildup in Asian countries, one needs to assume that the expected output cost of a currency crisis in Asia amounts to more than 60 percent of GDP, more than ten times the corresponding cost in Latin America.

Jeanne discusses possible interpretations for this puzzle. The first candidate is mercantilism, in which hoarding of international reserves is aimed at keeping the domestic currency undervalued, as part of an export-led growth strategy. ${ }^{3}$ Jeanne points out the theoretical and empirical challenges involved in modeling and testing this hypothesis. He also reports an interesting observation: the change in the reserves-GDP ratio is positively correlated with capital account restrictions. This correlation is the opposite of what one would expect based on the precautionary view of reserves accumulation, which predicts that countries with a more open capital account should hold more precautionary reserves because they are more vulnerable to volatile capital flows. In the next section I will show that this finding is consistent with the outcome of a competitive hoarding game.

3. Dooley, Folkerts-Landau, and Garber (2004). 
A closer look at the 2000-05 data in Jeanne's sample of countries indicates that reserves accumulation is strongly correlated with the current account surplus and not correlated at all with the change in gross external liabilities. This suggests that, to a first approximation, the accumulation of reserves reflects net export flows rather than balance sheet operations. The change in the reserves-GDP ratio is also positively correlated with the real GDP growth rate. This is puzzling if one thinks that high-growth developing countries should be importing foreign capital to finance their development. Yet this correlation is only one piece of a complex puzzle reported elsewhere by Jeanne himself with Pierre-Olivier Gourinchas: rapidly growing developing countries tend to export capital, an enigma that is explained in part by reserves accumulation. ${ }^{4}$

Jeanne closes the paper with a discussion of several policy implications. The governments of emerging market countries have started to mitigate the opportunity costs of hoarding large reserves by transferring a fraction of their foreign exchange reserves from the central bank to sovereign wealth funds. These funds are mandated to invest in a more diversified portfolio and at a longer horizon than central banks normally do, and they frequently are managed by quasi-independent entities (such as the recently established Korean Investment Corporation and the Chinese State Foreign Exchange Investment Corporation, as well as some older funds including Norway's oil fund). The assets of these sovereign wealth funds amount to about $\$ 2$ trillion today and are projected to increase rapidly in the future, becoming a major force in the international financial system. Jeanne considers the possible impact of portfolio diversification following attempts by these entities to scale down the dollar share of their international reserves. He finds that the impact of a gradual diversification would be moderate, decreasing net demand for U.S. assets by an estimated 0.5 percent of the outstanding stock, while the net demand for non-U.S. assets would increase by 0.66 percent of the stock. ${ }^{5}$

4. Gourinchas and Jeanne (2006). See Aizenman, Pinto, and Radziwill (2007) and Prasad, Rajan, and Subramanian (this volume) for further findings and interpretations of the positive association between economic growth and current account surpluses.

5. The impact would be larger if the substitutability between dollar debt and other currency debt is low, as international reserves diversification by major central banks may imply a net supply exceeding 7 percent of the outstanding stock if one restricts attention to marketable U.S. Treasury debt (reflecting the fact that the foreign official sector holds about one-third of the outstanding U.S. government debt). 
ALTERNATIVE INTERPRETATIONS OF RECENT RESERVES HOARDING. I now turn to some possible interpretations of the puzzle that Jeanne has identified. My starting point applies the logic of revealed preferences to argue that the continued large hoarding of international reserves by developing countries must reflect systemic forces supporting this trend. The challenge is to identify those forces and the conditions that may induce changes in the observed patterns. This requires venturing beyond the domain of the representative agent paradigm and entails some conjectures that deserve a more careful evaluation.

Competitive hoarding. The view that ascribes the large increase in hoarding of reserves to self-insurance faces a well-known challenger in a modern incarnation of mercantilism: the view that reserves accumulation is triggered by concerns about export competitiveness. This explanation has been advanced by Michael Dooley, David Folkerts-Landau, and Peter Garber, especially in the context of Asia. ${ }^{6}$ They interpret reserves accumulation as a by-product of export promotion, undertaken in Asia's case as a means of absorbing abundant labor migrating from the traditional sectors, especially agriculture. Although intellectually intriguing, this interpretation remains debatable. Some have pointed out that strong export growth in East Asia is nothing new-indeed, it is an important part of the story there since the 1950s. Yet the large increase in reserves has happened mostly since 1997. Jaewoo Lee and I tested the importance of precautionary and mercantilist motives in accounting for the hoarding of international reserves by developing countries during 1980-2000. ${ }^{7}$ Although we found that certain variables associated with the mercantilist motive (such as lagged export growth and deviation of exchange rates from purchasing power parity) are statistically significant, their economic importance is small and dwarfed by other variables. Overall, our empirical results were consistent with an explanation based on precautionary demand. The inability of empirical research to validate a robust economic role for mercantilist hoarding through its impact on the real exchange rate, together with the acceleration of large hoardings in East Asia during 2001-07, remains a puzzle.

Arguably, one might reconcile the mercantilist view with the limited support of mercantilism found in cross-country regressions by invoking

6. Dooley, Folkerts-Landau, and Garber (2004).

7. Aizenman and Lee (2005). 
the concept of competitive hoarding by countries following an exportoriented growth strategy and competing with each other in the same third markets, such as the United States. Such hoarding might be triggered by more vigorous competition in industries approaching excess capacity. My figure 1 depicts an example of such a competitive hoarding game, one akin to Harry Johnson's classic tariff war model. ${ }^{8}$

The figure illustrates the behavior of two emerging market countries, $\mathrm{H}$ and $\mathrm{F}$, exporting similar products to a third market. Increased hoarding of reserves by either country would depreciate its currency, thereby improving its export competitiveness vis-à-vis the other country. Assume that both $\mathrm{H}$ and $\mathrm{F}$ seek to balance the gain from export promotion against the costs of hoarding reserves (reflecting costly sterilization and other indirect costs). The optimal international reserves level in the absence of competitive hoarding is normalized to 1 , given by point $\mathrm{O}$. Curves $\mathrm{HH}$ and $\mathrm{FF}$ are the reaction functions of $\mathrm{H}$ and $\mathrm{F}$ in the competitive hoarding game. Curve $\mathrm{W}_{\mathrm{o}}$ is H's indifference curve, consisting of configurations of domestic and foreign reserves where H's utility equals the benchmark of no competitive hoarding. $\mathrm{H}$ is worse off relative to the no-hoarding equilibrium at points above curve $\mathrm{W}_{\mathrm{o}}$. The Nash equilibrium of the competitive hoarding game is depicted by the intersection of curves $\mathrm{HH}$ and FF, at point $\mathrm{S}$. When the two emerging market countries have symmetric costs associated with hoarding reserves (top panel), competitive hoarding tends to dissipate most of the competitiveness gains, leading to self-defeating ("beggar-yourself") outcomes and excessive hoarding. If, however, the countries have asymmetric costs of accumulating reserves (bottom panel), a country with a low enough cost of sterilization may win the hoarding war: its noncooperative outcome, which lies below the curve $\mathrm{W}_{\mathrm{o}}$, is superior to the cooperative one, in a manner akin to the "beggar-thy-neighbor" outcome of asymmetric tariff wars. ${ }^{9}$

Financial repression of the type observed in China may reduce its sterilization costs, thereby increasing the aggressiveness of its sterilization and ultimately increasing its international reserves. Consequently, competitive hoarding in circumstances where financial repression reduces the cost of sterilization is consistent with Jeanne's finding of a negative association between hoarding and financial integration.

8. Johnson (1953).

9. Aizenman and Lee (2006). 
Figure 1. Two Cases of Competitive Hoarding in Two Emerging Market Countries

Foreign reserves ${ }^{b}$

Symmetric case $\mathrm{c}^{\mathrm{a}}$

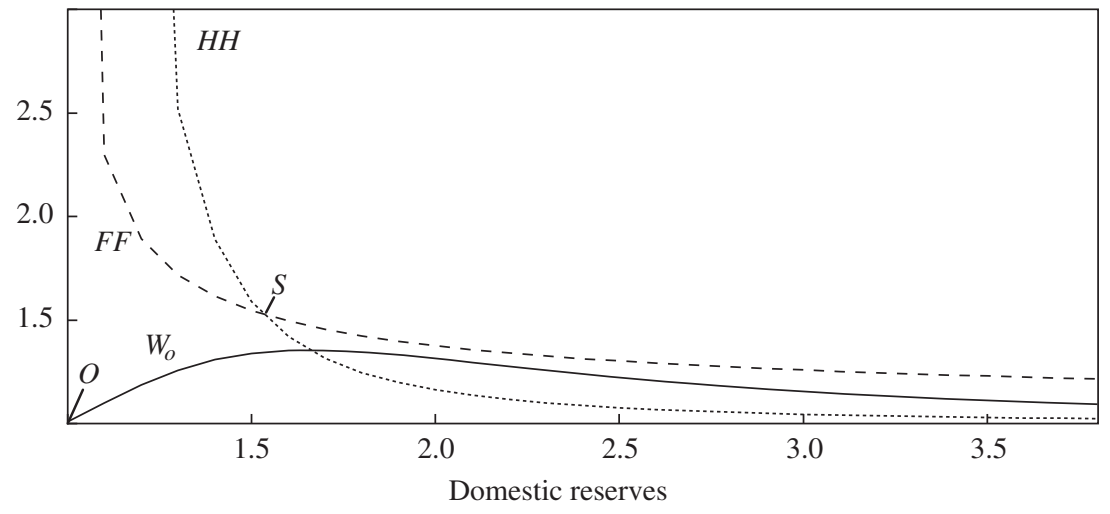

Foreign reserves

Asymmetric case ${ }^{\mathrm{c}}$

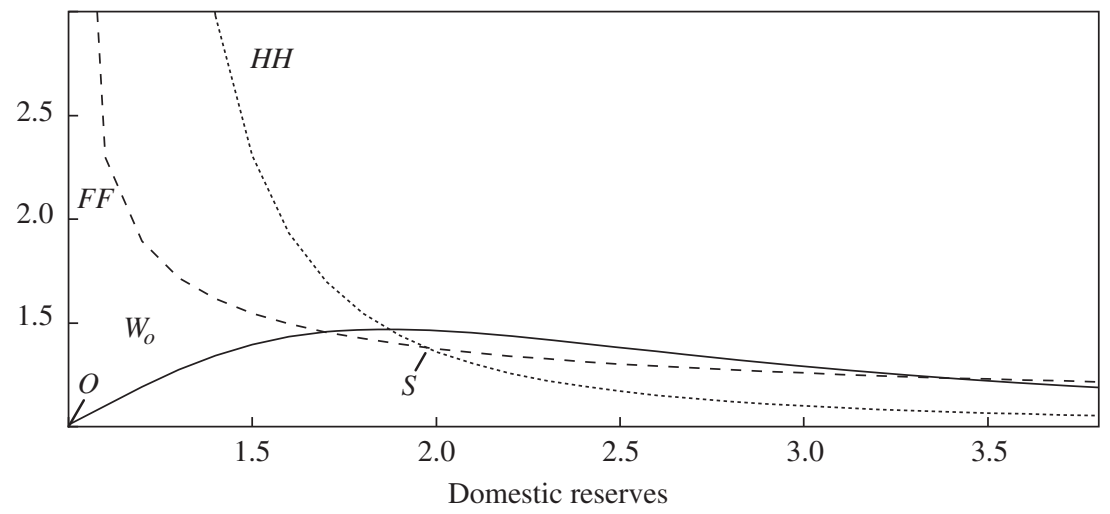

Source: Aizenman and Lee (2006).

a. The "beggar-yourself" case; the home country $(\mathrm{H})$ and the foreign country $(\mathrm{F})$ have the same sterilization costs.

b. The optimal level of reserves is normalized to one unit.

c. The "beggar-thy-neighbor" case; $\mathrm{H}$ has lower sterilization costs than F.

Arguably, the unique role of China in a hoarding game is consistent with recent patterns of sterilization. The accumulation of international reserves accelerated during 2000-05 to more than $\$ 100$ billion annually on average and has been associated with sizable current account surpluses and 
inflows of capital of about $\$ 60$ billion and $\$ 50$ billion, respectively. ${ }^{10}$ Reuven Glick and I also found a significant increase in the coefficient of sterilization following the 1997-98 crisis, a trend that continues today and applies well beyond Asia. ${ }^{11}$ These findings suggest that growing financial integration has been associated with extensive hoarding of international reserves. Notwithstanding concerns about sterilization costs, reserves hoarding and sterilization have complemented each other during the last ten years, as developing countries have increased the intensity of both. The costs of sterilization have so far been well below the perceived benefits of monetary stability and the wish to hoard international reserves.

These trends are consistent with aggressive sterilization applied by China, where large inflows of capital and large current account surpluses are associated with sterilization. If China's sterilization costs are lower than those of Korea and other countries competing with China in the U.S. market, China may ultimately win the hoarding game. China's sheer size and low sterilization costs, probably due to financial repression there, may force Korea and Japan to keep hoarding international reserves in order to prevent deeper erosion of their competitiveness. ${ }^{12}$

Such behavior may also explain the inability to find empirical evidence of a robust economic role for the mercantilist approach, as most of the effects tend to dissipate quickly. Competitive hoarding may also reflect coordination failure. If China is the winner by virtue of its low sterilization costs and size, other Asian countries may be made worse off (while, arguably, the welfare impact of the hoarding game on the United States is ambiguous). It also suggests the possibility of gains from regional coordination, possibly in the form of a regional fund, although China may be less eager than other East Asian countries to participate in such a fund. Competitive hoarding is also consistent with the possibility that demand for international reserves is interdependent,

10. These averages mask the remarkable acceleration of China's annual hoardings, from close to zero during 2000 , to about $\$ 100$ billion, $\$ 200$ billion, and $\$ 250$ billion during 2003, 2004, and 2006, respectively.

11. Aizenman and Glick (2007). The "coefficient of sterilization" measures the marginal change of domestic credit associated with hoarding international reserves. Specifically, we regress the four-quarter change in net domestic assets on the four-quarter increase in net foreign assets held by the central bank, scaled by reserve money stock, controlling for nominal GDP growth.

12. Arguably, it may also induce Korea and Japan to invest directly in China, in an attempt to minimize their losses in the hoarding game. 
as XingWang Qian reported in a study of ten East Asian economies. ${ }^{13}$ They found, controlling for conventional variables explaining reserves hoarding, that a one-dollar increase in international reserves by one country was associated with an increase in reserves by the other nine of about 60 cents.

Exposure to latent domestic instability. To put Chinese policies in the perspective of the historical development of East Asia, note that the history of Japan and Korea suggests the near absence of mercantilist hoarding of international reserves during their phase of fast growth, and the prevalence of export promotion by subsidizing heavily the cost of capital in targeted sectors. This has been accomplished with the help of the state banking system and occasionally with the tacit involvement of the central bank. The legacy of subsidized capital has been a rapid increase in M2 and the accumulation of nonperforming loans. Floundering economic growth subsequently led to large hoarding of reserves in both Japan (after 1992) and Korea (after 1997), probably both from mercantilist motives and as self-insurance in view of the growing fragility of their banking systems. These perspectives suggest that the recent massive hoarding of reserves by China may reflect a hybrid of mercantilist and self-insurance motives. ${ }^{14}$

Other explanations of reserves hoarding by China invoke political economy considerations. The Chinese government faces multiple challenges: managing an economic take-off of unprecedented global magnitude, uncertainty regarding the political regime's survival, growing income disparities, a buildup of nonperforming loans, and growing dependency on international trade. An abundance of savings in China provides an opportunity to mitigate the risk of domestic instability by aggressively hoarding international reserves, thereby reducing both the risk of real exchange rate instability and the risk of inflation triggered by domestic crisis. ${ }^{15}$ This view is consistent with a 2006 report by Ernst \&

13. Qian (2006).

14. See Aizenman and Lee (2006).

15. Arguably, if China were to face a banking crisis of the type experienced by Argentina, a sizable cushion of international reserves would allow the authorities to avoid the collapse of financial intermediation and higher inflation that Argentina suffered. Indeed, one could argue that the sheer size of Chinese international reserves may prevent a run on its banking system in the first place. 
Young that China's nonperforming loans almost equaled its international reserves. ${ }^{16}$ It also suggests that, for countries averse to real exchange rate volatility and inflation, actually usable international reserves may be limited to what is left over after covering short-term external debt and after any provisions for nonperforming loans in the domestic banking system.

TESTING THE SELF-INSURANCE MODEL IN CHINA AND THE "PESO PROBLEM." Systematic attempts to test the self-insurance model are challenged by a version of the "peso problem," whereby current reserve holdings appear inefficient given current conditions but may be justified by expectations of future conditions. For example, the probability of a deep crisis in China may be low, but the potential damage of such a crisis may be immense. China's take-off remains unique in terms of its sheer size: China's share of global GDP (adjusted for purchasing power parity) tripled within just twenty-five years, from about 5 percent in 1977 to about 15 percent in 2003. This suggests that the experience of other countries is of little help in determining China's optimal level of reserves. The econometric challenges associated with quantifying the self-insurance needs of a country are akin to the challenge of quantifying the optimal design of highways in the San Francisco Bay area. An uninformed tourist visiting San Francisco might conclude that highways there are overbuilt and conjecture that San Franciscans have a strange preference for heavily reinforced roads. Certainly the data of the last fifteen years do nothing to suggest otherwise. Only those who know the city's history, including the great earthquake of 1906, will understand why highways there are designed the way they are, and indeed one may ask why some highways remain underbuilt to this day. Similarly, although China has been reasonably tranquil, economically and politically, during the last twenty years, the region's history during the twentieth century is one of repeated "earthquakes," some triggered domestically and some abroad.

EXTENSIONS OF THE MODEL. I close with several short comments on possible extensions that may provide a better interpretation of the patterns of hoarding in Latin America while also addressing some of the issues involved in dealing with Asia.

16. Jim Peterson, "Balance Sheet: China Offers Fertile Soil for Investor Unhappiness," International Herald Tribune, September 11, 2006. 
International reserves and sovereign default. The representative agent model used by Jeanne is more appropriate to countries that, although exposed to possible sudden stops and foreign currency crises, view the external default option as too costly to be contemplated. (Korea during the last thirty years is an example.) Understanding the role of international reserves in Latin America, by contrast, requires modeling the implications of sovereign default for international reserves. As a practical matter, international reserves are beyond creditors' reach. This implies that, for countries willing to contemplate it, sovereign default is an alternative, independent instrument for consumption smoothing. Nancy Marion and I have provided a model and some empirical evidence indicating that, in these circumstances, greater political instability and polarization tend to reduce reserves hoarding and to increase sovereign borrowing. ${ }^{17}$ This interpretation may account for Jeanne's observation that, in 2000, Latin America held significantly less reserves than his benchmark model predicted.

Saving and reserves hoarding. With integration of national capital markets still limited, one expects that, all else equal, countries with higher saving rates would opt to hoard more reserves. Hence the same factors that account for the large gap in saving rates between Latin America and East Asia may also explain their different behaviors with respect to international reserves.

International reserves and the real exchange rate. Countries may hoard reserves as a means of stabilizing the real exchange rate in the presence of volatile terms of trade shocks and volatile short-term capital flows. ${ }^{18}$ This argument is reinforced by Philippe Aghion and others, who found that real exchange rate volatility reduces growth in countries with relatively weak financial development. ${ }^{19}$ Hence factors that mitigate real exchange rate volatility may be associated with superior economic performance. This is of special relevance to commodity-exporting countries and countries with shallow financial systems. Extensions of Jeanne's model that would allow for adverse effects of real exchange rate volatility would imply another rationale for hoarding reserves.

Diversification and agency problems. The lack of deeper diversification of international reserves may be partly due to agency problems. Central

17. Aizenman and Marion (2003).

18. See Aizenman (2006).

19. Aghion and others (2006). 
banks may be loss averse, in that the cost of holding too little reserves may be much higher than the opportunity cost of holding too much. ${ }^{20}$ If a central bank's loss aversion exceeds that of the representative consumer, a good case can be made for putting some of the international reserves into a "future generation" fund managed by the treasury or some other agency, along the lines of Jeanne's discussion.

In conclusion, Jeanne's paper is a first-rate contribution to the debate over the recent large buildup of international reserves in some countries. The quest for a unified theory and empirical specification of international reserves holdings, although admirable, may not be feasible given the pace of global change. It is constructive to view the observed patterns of international reserves hoarding as the aggregate result of several motives, whose relative importance varies over time. Taking such an eclectic approach, one may conjecture that the hoarding phenomenon has gone through several phases. The first phase, in the immediate aftermath of the East Asian crisis, was dominated by countries seeking self-insurance against exposure to foreign shocks. Countries stunned by the 1997 crisis hedged their growing financial integration by aggressively hoarding international reserves. Yet, as Jeanne convincingly illustrates, the self-insurance interpretation fails to account for the size of the reserves buildup in emerging market countries after 2000. My comments suggest that the levels of reserve holdings observed recently indicate the turn to a second phase, which may be better explained by competitive hoarding, by self-insurance against latent domestic instability, and by exposure to instability associated with a growing weakness of commercial banks' balance sheets.

Lawrence H. Summers: Soon after I arrived at the Treasury as under secretary of international affairs in 1993, I was briefed about the Exchange Stabilization Fund. One of the first questions I asked was why this fund, which holds the foreign currency reserves that the Treasury uses to intervene in foreign exchange markets, was the size that it was. I received two answers. One came from Treasury staff and consisted of a lengthy disquisition on the series of historical events leading from the fund's beginnings to date. The other came from then-Federal Reserve chairman Alan Greenspan, who explained how he and Edwin Truman, when Truman was on the staff of the Federal Open Market Committee, had undertaken a research program to 
determine the optimal level of reserves for the United States. Greenspan reported to me somewhat sheepishly their conclusion that, depending upon certain assumptions that were difficult to pin down, the optimal level was somewhere between $\$ 20$ billion and \$2 trillion. So they had abandoned that particular effort.

I am glad to see Olivier Jeanne pick up the torch again and try to analyze the costs and benefits of reserves and arrive at some concept of an optimal level. And I broadly agree with his conclusions. I agree that it is difficult to account for the rise in reserves in East Asia on the basis of a plausible precautionary hypothesis. I agree that those resources should be invested in more imaginative ways, accepting more risk in exchange for a higher return, than they are today. I agree that doing so will not likely cause huge disruptions in the global capital market. And I agree that current patterns of reserves holdings have something to do with mercantilism on the part of the countries holding them. But I am somewhat more skeptical of several aspects of Jeanne's analysis.

Let me first make three points with respect to the cost-benefit analysis of reserves. The first concerns possible nonlinearities. The basic proposition of any cost-benefit analysis that seeks some optimum is that marginal benefit is equal to marginal cost. Unfortunately, in the case of reserves, it is very difficult to establish the shape of either the benefit function or the cost function. With respect to the use of reserves in crisis prevention, that is, reducing the probability of a crisis, it is hard to demonstrate conclusively that there are any statistically significant benefits at all. How those benefits vary for a given change in reserves when reserves are, say, two times short-term debt versus four times short-term debt is even more difficult to estimate. Thus Jeanne's results are heavily driven by his choice of functional form. It would be worth experimenting with alternative, nonlinear specifications, although I suspect it would be difficult to gauge the results with any precision.

Second, Jeanne's analysis requires certain assumptions about the mechanics not only of crisis prevention, but also of crisis mitigation, or how reserves are to be used when a crisis actually happens. These assumptions may not be appropriate. For example, the premise of the analysis using the so-called sudden stop formulation, which looks at changes in the capital account, is that the response to changes in the capital account is a change in the holdings of reserves that maintains domestic absorption approximately constant. Yet this is something that the International Monetary Fund, the 
institution for which Jeanne works, would never stand for. Rather, IMF conditionality would typically not allow reserves to be used to permit increased absorption but would instead insist that they be used for sterilized intervention-thereby reducing their efficacy in maintaining level output and consumption.

Third, I am not entirely persuaded by the cost side of the analysis. In a perfect capital market, where all assets are perfect substitutes and reserves are financed by issuing domestic debt, holding reserves costs nothing at all. Indeed, to the extent that domestic debt is issued to finance investment in risky international assets to which the country's citizens would not otherwise have access, reserves are plausibly welfare enhancing. (The argument is similar to that made by Peter Diamond and others, that there is a gain to investing a portion of the Social Security trust fund in equities. ${ }^{1}$ ) The costs of reserves accumulation, I think, lie in rather different areas than those explored here: in the complexity posed for macroeconomic management, and in the moral hazards for policymaking associated with the availability of large amounts of reserves. Perhaps most important, the costs of reserves lie in the consequences, when the assumption of perfect substitutability of assets breaks down, of the (presumably transitory) change in the real exchange rate that results from an intervention that changes the relative supplies of assets.

In short, I find neither the paper's analysis of costs nor its analysis of benefits entirely compelling, and therefore the paper's comparison of optimal with current levels of reserves does not seem to me the most persuasive approach to drawing inferences about the motives of countries that hold large reserves. Perhaps a rather simpler approach is more revealing: Was anyone worried in 2002 about inadequate reserves in the major countries at issue? No. Therefore, if reserves have increased severalfold since then, it does not seem plausible to explain them on the basis of a precautionary motive. To put it another way, does anyone believe that if China, for example, could have maintained the same exchange rate path with half as much reserves accumulation over the last three years, the Chinese authorities would have been unhappy about it? If, as it seems to me, they would not have been, the implication is fairly clear that China's reserves accumulation is an endogenous response to a decision not about the level of reserves but about exchange rate policy. That decision may or may not,

1. Diamond and Geanakoplos (2003). 
in a full domestic calculus, have been a wise one. But the simple facts of the case - what China's policymakers said they were doing, and what they actually did—suggest that their accumulation of reserves was primarily a consequence of their exchange rate policy decisions. And the same can probably be said of the other East Asian countries.

If that is so, then the question of how to invest those reserves arises, and here Jeanne and I are in complete agreement. I have argued for some time that any reserves that the authorities do not envision using immediately and proximately in a crisis could surely be invested in a more productive vehicle than U.S. Treasury bills. Just as it would be financial malpractice for a defined-benefit pension fund to invest its reserves only in Treasury bills, so it must be with respect to government reserves that have a very long horizon. There are, as Jeanne recognizes, a variety of institutional issues involved in managing reserves in a more aggressive way. But these issues seem much smaller to me than in the case of investing the Social Security trust fund in equities, because what is envisioned here is the external investment of the reserves: to invest them domestically would compromise the macroeconomic objectives associated with reserves management. Since it is domestic investment that raises the most serious political issues, investment of reserves raises fewer concerns. (This assumes that investments are portfolio investments made through asset management intermediaries rather than direct investments, which raise a number of complex issues.)

The final question that this discussion raises is about the international surveillance mechanism. It is only a small exaggeration to say that, under traditional international norms, if a country makes an inappropriate decision about how much money it is going to borrow from its own citizens, that becomes a matter of great and urgent concern for the international community and will be a focal point of IMF surveillance. If, on the other hand, a country chooses to intervene in the foreign exchange market so as to cause its exchange rate and its trade relations to be very different from what they otherwise would have been, that, under current norms, is merely a matter of the country's choice of exchange rate regime and thus lies outside the purview of the IMF. Yet in a world where flows of capital out of many emerging market countries are large, to the extent those flows reflect not private investment decisions but rather conscious government policies directed at moving exchange rates in a particular direction, those decisions are surely an appropriate object of international surveillance and discus- 
sion. I hope that the recently debated reforms in IMF surveillance policy will redress this concern.

So, although I appreciate Jeanne's arguments, which are surely correct, that there are many countries that are not accumulating excessive reserves, and that reserves can be appropriately used for collective insurance, it seems to me there is a much larger issue at stake. That is whether something that is presumptively a nonmarket outcome, namely, a public decision to pursue intervention policies to cause exchange rates to differ from what market forces would determine, should be the subject of a more active discussion among the international community, led by the IMF. That it should be seems the most obvious implication of this research for IMF policy. As I said at the outset, it is enormously difficult to construct careful and rigorous models that will yield precise conclusions on these matters, and I have some questions about the particular model presented here. Nonetheless I think this is a very valuable undertaking that will eventually help us understand what I think is a major new feature of the international financial system, and for that we can be very grateful.

General discussion: Richard Cooper reminded the panel that in the 1960s there had been a lively literature on the optimum level of reserve holdings. He reported, however, that he had never met an official who thought in terms of optimal reserves; it should not be surprising, then, that reserves accumulation in many developing economies is not in accord with the normative prescriptions of Olivier Jeanne's model. Cooper suggested that, in order to understand the large international reserves in emerging market countries, one could simply refer to the main lesson that came out of the financial crises of the 1990s: do not run a current account deficit that is financed by private capital inflows. If the officials of such countries have indeed learned this lesson, they will have targeted a balanced current account and should therefore, in the buoyant world economy of recent years, find themselves with a current account surplus and growing reserves. Reserves accumulation, in other words, has been a by-product of other policies. Of course, when reserves fall uncomfortably low, officials will target an increase, but one should not worry too much if reserves exceed their notional target.

Cooper agreed with the paper's conclusion that the reserves of some Asian countries exceed what can be justified on a precautionary basis, but also with the paper's observation that most of these countries are slowly 
moving funds out of central bank reserves and into so-called sovereign wealth accounts. China, for example, is considering creating a $\$ 200$ billion overseas investment fund to improve the return on its assets. Most of the official investment funds that already exist are small, Norway's being the largest. Cooper asserted that the consequences of a world financial market in which some of the major investors are official investment funds with assets on the scale of $\$ 100$ billion or $\$ 200$ billion, and the rules that will govern the investment of such funds, are important topics for future analysis.

Cooper noted that the extraordinarily rapid aging of some East Asian societies suggests a reason for reserves accumulation that was missing from Jeanne's analysis. These societies are eventually going to have to rely on foreign assets to maintain their consumption. Ideally, the private residents of those countries would be permitted to invest abroad, and they would surely do so if permitted. But except in Hong Kong, institutional and information constraints are strong deterrents. This situation will undoubtedly change eventually, but for the time being Asian central banks are effectively acting as a nonoptimizing intermediary in their citizens' foreign investment.

Replying to Lawrence Summers' point regarding the rationale for the current size of the Treasury's Exchange Stabilization Fund, Cooper noted that the fund is a historical legacy, determined by gold profits and the U.S. revaluation of the price of gold in the 1930s; there was no optimization involved at all.

Raghuram Rajan, echoing Cooper's remarks, agreed that in countries with severe restrictions on private capital flows the central bank's actions substitute for what would otherwise be private outflows. The question is how rapidly to remove the restrictions that today create distortions in saving and investment. He suggested that central banks' perception of the risks that accompany removal of restrictions on private transactions inhibits reform. The People's Bank of China, for example, is worried about the magnitude of private outflows that would result from relaxing its capital controls. In particular, given the poor quality of China's banking system, and given that the ratio of bank credit to GDP is well over 100 percent, one might reasonably expect a tremendous outflow of capital from China in the absence of controls. One mechanism that would allow for measured increases in private capital outflows would be for the central bank to set up a closed-end investment fund that is allowed to invest in for- 
eign assets while maintaining control over the number of shares sold to domestic investors.

Eswar Prasad stressed the potential costs to a developing economy of an undervalued currency. In China, for example, the financial repression that results from undervaluation dictates a ceiling on deposit rates of about 3 percent, which, with inflation at comparable levels, amounts to a zero real rate of return. He suggested that it would be useful to know, in the context of Jeanne's model, how reserves accumulation affects the domestic rate of interest, providing an indication of the potential costs of financial repression implicit in accumulating reserves. He observed that because these costs of repression are largely hidden, spread throughout the financial system, the political system is likely to be biased toward undervaluation, with its more visible benefits for export growth. And he suggested that the costs of repression need to be taken into account when considering a build-up of reserves for other purposes that have been suggested, such as bank recapitalization or the accumulation of foreign assets to cover the needs of an aging society.

In a different vein, Prasad suggested that Jeanne's model overlooked the distributional effects of crises. These effects can have a substantial social cost. Even when a crisis is not large in terms of GDP, the distributional effects can still be enormous. In an economy like China, with a large number of unemployed, both disguised and undisguised, any disturbance could push people over the edge, setting off political and social instability. The Chinese authorities care a lot more about this cost than about the cost to output. 


\section{References}

Aghion, Philippe, and others. 2006. "Exchange Rate Volatility and Productivity Growth: The Role of Financial Development.” Working Paper 12117. Cambridge, Mass.: National Bureau of Economic Research (May).

Aizenman, Joshua. 2006. "International Reserves Management and the Current Account." Working Paper 12734. Cambridge, Mass.: National Bureau of Economic Research (December). Forthcoming in Current Account and External Financing, Tenth Annual Conference Proceedings, Central Bank of Chile, edited by Kevin Cowan, Sebastian Edwards, and Rodrigo Valdés. Santiago: Central Bank of Chile.

Aizenman, Joshua, and Reuven Glick. 2007. "Sterilization, Financial Liberalization, and Global Integration." Working paper. University of California, Santa Cruz, and Federal Reserve Bank of San Francisco.

Aizenman, Joshua, and Jaewoo Lee. 2005. "International Reserves: Precautionary vs. Mercantilist Views, Theory and Evidence." Working Paper 05/198. Washington: International Monetary Fund.

_. 2006. "Financial versus Monetary Mercantilism-Long-run View of Large International Reserves Hoarding." Working Paper 12718. Cambridge, Mass.: National Bureau of Economic Research (December).

Aizenman, Joshua, Yeonho Lee, and Yeongseop Rhee. 2004. "International Reserves Management and Capital Mobility in a Volatile World: Policy Considerations and a Case Study of Korea." Working Paper 10534. Cambridge, Mass.: National Bureau of Economic Research (June).

Aizenman, Joshua, and Nancy Marion, 2003. "The High Demand for International Reserves in the Far East: What Is Going On?" Journal of the Japanese and International Economies 17, no. 3: 370-400.

Aizenman, Joshua, Brian Pinto, and Artur Radziwill. 2007. "Sources for Financing Domestic Capital-Is Foreign Saving a Viable Option for Developing Countries?" Journal of International Money and Finance 26, no. 5: 682-702.

Beck, Thorsten, Asli Demirgüç-Kunt, and Ross E. Levine. 1999. "A New Database on Financial Development and Structure." Policy Research Working Paper 2146. Washington: World Bank (July).

Becker, Torbjörn, and Paolo Mauro. 2006. "Output Drops and the Shocks That Matter." Working Paper 06/172. Washington: International Monetary Fund (July).

Becker, Torbjörn, and others. 2007. "Country Insurance: The Role of Domestic Policies." Occasional Paper 254. Washington: International Monetary Fund.

Ben Bassat, Avraham, and Daniel Gottlieb. 1992. "Optimal International Reserves and Sovereign Risk." Journal of International Economics 33 (November): 345-62.

Berg, Andrew, Eduardo Borensztein, and Catherine Pattillo. 2005. "Assessing Early Warning Systems: How Have They Worked in Practice?" International Monetary Fund Staff Papers 52, no. 3: 462-502. 
Bird, Graham, and Ramkishen Rajan. 2003. "Too Much of a Good Thing? The Adequacy of International Reserves in the Aftermath of Crises." The World Economy 26, no. 6: 873-91.

Bussière, Matthieu, and Christian Mulder. 1999. "External Vulnerability in Emerging Market Economies: How High Liquidity Can Offset Weak Fundamentals and the Effects of Contagion." Working Paper 99/88. Washington: International Monetary Fund (July).

Caballero, Ricardo J. 2006. "On the Macroeconomics of Assets Shortages." Working Paper 12753. Cambridge, Mass.: National Bureau of Economic Research (December).

Caballero, Ricardo J., and Arvind Krishnamurthy. 2004. "Smoothing Sudden Stops.” Journal of Economic Theory 119, no. 1: 104-27.

Caballero, Ricardo J., and Stavros Panageas. 2005. "A Quantitative Model of Sudden Stops and External Liquidity Management." Working Paper 11293. Cambridge, Mass.: National Bureau of Economic Research (May).

Calvo, Guillermo A. 1996. "Capital Flows and Macroeconomic Management: Tequila Lessons." International Journal of Finance and Economics 1, no. 3: 207-23.

1998. "Capital Flows and Capital-Market Crises: The Simple Economics of Sudden Stops." Journal of Applied Economics 1, no. 1: 35-54.

- 2006. "Monetary Policy Challenges in Emerging Markets: Sudden Stop, Liability Dollarization, and Lender of Last Resort." Working Paper 12788. Cambridge, Mass.: National Bureau of Economic Research (December).

Calvo, Guillermo A., Alejandro Izquierdo, and Luis F. Mejía. 2004. "On the Empirics of Sudden Stops: The Relevance of Balance-Sheet Effects." Working Paper 10520. Cambridge, Mass.: National Bureau of Economic Research (May).

Caselli, Francesco. 2007. "The Marginal Product of Capital." Quarterly Journal of Economics 122, no. 2: 535-68.

Chang, Roberto, and Andres Velasco. 2000. "Liquidity Crises in Emerging Markets: Theory and Policy." In NBER Macroeconomics Annual 1999, edited by Ben S. Bernanke and Julio Rotemberg. MIT Press.

Chinn, Menzie D., and Hiro Ito. 2005. "What Matters for Financial Development? Capital Controls, Institutions, and Interactions." Working Paper 11370. Cambridge, Mass.: National Bureau of Economic Research (May).

De Beaufort-Wijnholds, J. Onno, and Arend Kapteyn. 2001. "Reserve Adequacy in Emerging Market Economies.” Working Paper 01/143. Washington: International Monetary Fund (September).

Detragiache, Enrica, and Antonio Spilimbergo. 2001. "Crises and Liquidity: Evidence and Interpretation." Working Paper 01/2. Washington: International Monetary Fund (January).

Diamond, Peter, and John Geanakoplos. 2003. "Social Security Investment in Equities." American Economic Review 93, no. 4: 1047-74. 
Dooley, Michael P., David Folkerts-Landau, and Peter Garber. 2004. "The Revived Bretton Woods System: The Effects of Periphery Intervention and Reserve Management on Interest Rates and Exchange Rates in Center Countries." Working Paper 10332. Cambridge, Mass.: National Bureau of Economic Research (March).

Duffie, Darrell, Lasse Heje Pedersen, and Kenneth J. Singleton. 2003. "Modeling Sovereign Yield Spreads: A Case Study of Russian Debt." Journal of Finance 58, no. 1: 119-59.

Durdu, Ceyhun Bora, Enrique G. Mendoza, and Marco E. Terrones. 2007. "Precautionary Demand of Foreign Assets in Sudden Stop Economies: An Assessment of the New Mercantilism." Working Paper 13123. Cambridge, Mass.: National Bureau of Economic Research (May).

Edwards, Sebastian. 1985. "On the Interest-Rate Elasticity of the Demand for International Reserves: Some Evidence from Developing Countries.” Journal of International Money and Finance 4, no. 2: 287-95.

- 2001. "Capital Mobility and Economic Performance: Are Emerging Economies Different?” Working Paper 8076. Cambridge, Mass.: National Bureau of Economic Research (January).

- 2004. "Thirty Years of Current Account Imbalances, Current Account Reversals, and Sudden Stops." International Monetary Fund Staff Papers 51 (June): 1-49.

Eichengreen, Barry. 2006. "Insurance Underwriter or Financial Development Fund: What Role for Reserve Pooling in Latin America?" Working Paper 12451. Cambridge, Mass.: National Bureau of Economic Research (August).

Eichengreen, Barry, and Ashoka Mody. 2000. "What Explains Spreads on Emerging Market Debt?" In Capital Flows and the Emerging Economies: Theory, Evidence and Controversies, edited by Sebastian Edwards. University of Chicago Press.

European Central Bank. 2006. "The Accumulation of Foreign Reserves.” Occasional Paper 43. Frankfurt (February).

Flood, Robert P., and Peter M. Garber. 1984. "Collapsing Exchange-Rate Regimes: Some Linear Examples." Journal of International Economics 17 (August): 1-13.

Flood, Robert, and Nancy Marion. 2002. "Holding International Reserves in an Era of High Capital Mobility." In Brookings Trade Forum 2001, edited by Susan M. Collins and Dani Rodrik, pp. 1-47. Brookings.

Frankel, Jeffrey A., and Eduardo A. Cavallo. 2004. "Does Openness to Trade Make Countries More Vulnerable to Sudden Stops, or Less? Using Gravity to Establish Causality." Working Paper 10957. Cambridge, Mass.: National Bureau of Economic Research (December). 
Frankel, Jeffrey A., and Andrew K. Rose. 1996. "Currency Crashes in Emerging Markets: An Empirical Treatment." Journal of International Economics 41 (November): 351-66.

Frankel, Jeffrey A., and Shang-Jin Wei. 2005. "Managing Macroeconomic Crises: Policy Lessons." In Managing Economic Volatility and Crises: A Practitioner's Guide, edited by Joshua Aizenman and Brian Pinto. Cambridge University Press.

Frenkel, Jacob A., and Boyan Jovanovic. 1981. "Optimal International Reserves: A Stochastic Framework.” Economic Journal 91, no. 362: 507-14.

Garcia, Pablo S., and Claudio Soto. 2004. "Large Hoarding of International Reserves: Are They Worth It?” Working Paper 299. Santiago: Central Bank of Chile (December).

Ghosh, Atish, and others. 2007. "Modeling Aggregate Use of Fund ResourcesAnalytical Approaches and Medium-Term Projections." Working Paper 07/70. Washington: International Monetary Fund (March).

Gourinchas, Pierre-Olivier, and Olivier Jeanne. 2006. "Capital Flows to Developing Countries: The Allocation Puzzle." University of California, Berkeley, Department of Economics.

Hamada, Koichi, and Kazuo Ueda. 1977. "Random Walks and the Theory of Optimal International Reserves.” Economic Journal 87, no. 848: 722-42.

Hauner, David. 2005. “A Fiscal Price Tag for International Reserves.” Working Paper 05/81. Washington: International Monetary Fund (April).

Heller, H. Robert. 1966. "Optimal International Reserves.” Economic Journal 76, no. 302: 296-311.

Hutchison, Michael M., and Ilan Noy. 2006. "Sudden Stops and the Mexican Wave: Currency Crises, Capital Flow Reversals and Output Loss in Emerging Markets." Journal of Development Economics 79, no. 1: 225-48.

Hviding, Ketil, Michael Nowak, and Luca Antonio Ricci. 2004. "Can Higher Reserves Help Reduce Exchange Rate Volatility?” Working Paper 04/189. Washington: International Monetary Fund (October).

International Monetary Fund. 2000. "Debt- and Reserve-Related Indicators of External Vulnerability." IMF Board Paper. Washington (March) (www.imf. org/external/np/pdr/debtres/index.htm).

- 2001. "Issues in Reserves Adequacy and Management." IMF Board Paper. Washington (October) (www.imf.org/external/np/pdr/resad/2001/reserve. htm).

_ 2003. "Are Foreign Exchange Reserves in Asia Too High?" Chapter 2 in World Economic Outlook, pp. 78-92 (September). Washington: International Monetary Fund.

Jeanne, Olivier, and Romain Rancière. 2006. "The Optimal Level of International Reserves for Emerging Market Countries: Formulas and Applications.” Working Paper 06/229. Washington: International Monetary Fund (October). 
Jeanne, Olivier, and Charles Wyplosz. 2003. "The International Lender of Last Resort: How Large Is Large Enough?" In Managing Currency Crises in Emerging Markets, edited by Michael P. Dooley and Jeffrey A. Frankel. University of Chicago Press.

Jen, Stephen. 2007. "Currencies: How Big Could Sovereign Wealth Funds Be by 2015?” New York: Morgan Stanley Research Global (May).

Johnson, Harry G. 1953. "Optimum Tariffs and Retaliation.” Review of Economic Studies 21, no. 2: 142-53.

Johnson-Calari, Jennifer, and Malan Rietveld, eds. 2007. Sovereign Wealth Management. London: Central Banking Publications.

Kaminsky, Graciela, Saul Lizondo, and Carmen M. Reinhart. 1998. "Leading Indicators of Currency Crises." International Monetary Fund Staff Papers 45, no. 1: 1-48.

Knight, Malcolm D. 2006. "International Reserve Diversification and Disclosure." Speech at the Swiss National Bank/Institute for International Economics Conference, Zurich, September 8 (www.bis.org/speeches/sp060908.htm).

Krugman, Paul. 1979. "A Model of Balance-of-Payments Crises.” Journal of Money, Credit and Banking 11, no. 3: 311-25.

Lee, Jaewoo. 2004. "Insurance Value of International Reserves: An Option Pricing Approach.” Working Paper 04/175. Washington: International Monetary Fund (September).

Lane, Philip R., and Gian Maria Milesi-Ferretti. 2006. "The External Wealth of Nations Mark II: Revised and Extended Estimates of Foreign Assets and Liabilities, 1970-2004." Discussion Paper 5644. London: Centre for Economic Policy Research (April).

Levy Yeyati, Eduardo. 2006. "The Cost of Reserves.” Working Paper 10/2006. Buenos Aires: Centro de Investigación en Finanzas, Universidad Torcuato Di Tella (July).

Miller, Marcus, and Lei Zhang. 2006. "Fear and Market Failure: Global Imbalances and 'Self-Insurance.'” Discussion Paper 6000. London: Centre for Economic Policy Research (December).

Mohanty, M. S., and Philip Turner. 2006. "Foreign Exchange Reserve Accumulation in Emerging Markets: What Are the Domestic Implications?" BIS Quarterly Review (September): 39-52.

Morris, Stephen, and Hyun Song Shin. 1998. "Unique Equilibrium in a Model of Self-Fulfilling Currency Attacks." American Economic Review 88 no. 3: 587-97.

Mulder, Christian. 2000. "The Adequacy of International Reserve Levels: A New Approach.” In Risk Management for Central Bankers, edited by Steven F. Frowen, Robert Pringle, and Benedict Weller. London: Central Bank Publications. 
Parisi-Capone, Elisa, and Brad Setser. 2006. "Central Banks Active Participants in the Market for Treasuries with a Maturity of up to 10 Years." RGE Monitor. New York: Roubini Global Economics (October 17) (www.rgemonitor.com/ redir.php?sid=1\&tgid=10000\&clid=4042\&cid=152505).

Prasad, Eswar S., and Raghuram G. Rajan. 2005. "Controlled Capital Account Liberalization: A Proposal.” Policy Discussion Paper 05/7. Washington: International Monetary Fund (October).

Pringle, Robert, and Nick Carver, eds. 2005. RBS Reserve Management Trends 2005. London: Central Banking Publications.

Qian, XingWang. 2006. "Hoarding of International Reserves: Mrs Machlup's Wardrobe and the Joneses." University of California, Santa Cruz.

Quinn, Dennis P. 2000. "Democracy and International Financial Liberalization." McDonough School of Business, Georgetown University.

Reinhart, Carmen M., and Kenneth S. Rogoff. 2004. "The Modern History of Exchange Rate Arrangements: A Reinterpretation." Quarterly Journal of Economics 119, no. 1: 1-48.

Rodrik, Dani. 2006. "The Social Cost of Foreign Exchange Reserves." International Economic Journal 20, no. 3: 253-66.

Rozanov, Andrew. 2005. "Who Holds the Wealth of Nations?" Central Banking Journal 15, no. 4: 52-57.

Rudebusch, Glenn D., Brian P. Sack, and Eric T. Swanson. 2007. "Macroeconomic Implications of Changes in the Term Premium." Federal Reserve Bank of St. Louis Review 89, no. 4: 241-69.

Stiglitz, Joseph E. 2006. Making Globalization Work. W.W. Norton.

Summers, Lawrence H. 2006. "Reflections on Global Account Imbalances and Emerging Markets Reserves Accumulation.” L. K. Jha Memorial Lecture, Reserve Bank of India, Mumbai, March 24 (www.president.harvard.edu/ speeches/2006/0324_rbi.html).

Truman, Edwin M., and Anna Wong. 2006. "The Case for an International Reserve Diversification Standard.” Working Paper 06-2. Washington: Institute for International Economics (May).

Warnock, Francis E., and Veronica Cacdac Warnock. 2006. "International Capital Flows and U.S. Interest Rates.” Working Paper 12560. Cambridge, Mass.: National Bureau of Economic Research (October).

Wooldridge, Philip D. 2006. "The Changing Composition of Official Reserves." BIS Quarterly Review (September): 25-38. 
